\title{
Snakebite Envenoming Diagnosis and Diagnostics
}

\author{
Cecilie Knudsen ${ }^{1,2 *}$, Jonas A. Jürgensen ${ }^{1}$, Sofie Føns ${ }^{1}$, Aleksander M. Haack ${ }^{1}$, \\ Rasmus U. W. Friis ${ }^{1}$, Søren H. Dam ${ }^{1}$, Sean P. Bush ${ }^{3}$, Julian White ${ }^{4}$ and Andreas H. Laustsen ${ }^{1 *}$ \\ ${ }^{1}$ Department of Biotechnology and Biomedicine, Technical University of Denmark, Kongens Lyngby, Denmark, ${ }^{2}$ BioPorto \\ Diagnostics A/S, Hellerup, Denmark, ${ }^{3}$ Department of Emergency Medicine, Yale School of Medicine, New Haven, \\ CT, United States, ${ }^{4}$ Toxinology Department, Women's and Children's Hospital, North Adelaide, SA, Australia
}

\section{OPEN ACCESS}

Edited by:

Manuela Berto Pucca, Federal University of Roraima,

Brazil

Reviewed by: Sakthivel Vaiyapuri, University of Reading, United Kingdom Clara Guerra-Duarte, Ezequiel Dias Foundation (FUNED),

Brazil

*Correspondence: Cecilie Knudsen Cecknu@dtu.dk Andreas H. Laustsen Ahola@bio.dtu.dk

Specialty section: This article was submitted to Vaccines and Molecular Therapeutics, a section of the journal

Frontiers in Immunology

Received: 30 January 2021 Accepted: 29 March 2021

Published: 28 April 2021

Citation:

Knudsen C, Jürgensen JA, Føns $S$, Haack AM, Friis RUW, Dam SH,

Bush SP, White $J$ and Laustsen $A H$ (2021) Snakebite Envenoming

Diagnosis and Diagnostics.

Front. Immunol. 12:661457. doi: 10.3389/fimmu.2021.661457
Snakebite envenoming is predominantly an occupational disease of the rural tropics, causing death or permanent disability to hundreds of thousands of victims annually. The diagnosis of snakebite envenoming is commonly based on a combination of patient history and a syndromic approach. However, the availability of auxiliary diagnostic tests at the disposal of the clinicians vary from country to country, and the level of experience within snakebite diagnosis and intervention may be quite different for clinicians from different hospitals. As such, achieving timely diagnosis, and thus treatment, is a challenge faced by treating personnel around the globe. For years, much effort has gone into developing novel diagnostics to support diagnosis of snakebite victims, especially in rural areas of the tropics. Gaining access to affordable and rapid diagnostics could potentially facilitate more favorable patient outcomes due to early and appropriate treatment. This review aims to highlight regional differences in epidemiology and clinical snakebite management on a global scale, including an overview of the past and ongoing research efforts within snakebite diagnostics. Finally, the review is rounded off with a discussion on design considerations and potential benefits of novel snakebite diagnostics.

Keywords: envenoming, clinical toxinology, diagnosis, diagnostics, ophidism, snakebite management, syndromic approach

\section{INTRODUCTION}

Every year, people lose their livelihoods, limbs, and lives to a disease that is as neglected as it is ancient: Snakebite envenoming. The exact burden of snakebite envenoming is notoriously difficult to assess, because data on envenoming prevalence are scarce, and the available data points are often inaccurate or not representative for broader geographical areas (1-4). Nonetheless, studies suggest that mortality due to snakebite envenoming may exceed 125,000 deaths per year globally, while the number of people suffering permanent sequelae may be around 400,000, and the toll of associated disability-adjusted life years might add up to a total of over 6 million (4-8). To make matters worse, snakebite envenoming is both a disease mainly affecting the poor and a disease that leads to further impoverishment (7, 9-12). In spite of the immense burden of snakebite envenoming on victims, their families, and local communities, the disease remains largely neglected and has historically only received few resources, and limited efforts have gone into the development of better treatments and diagnostics (13). 
Once diagnosed, the mainstay treatment of severe envenoming is antivenom in combination with auxiliary treatment $(7,14,15)$. Monovalent antivenoms can be used when the species of the offending snake is known, while polyvalent antivenoms are useful in cases where the snake species has not been identified. However, the ability of polyvalent antivenoms to neutralize a broad range of venoms might come at the cost of decreased efficacy, as the relative proportion of antibodies in a polyvalent antivenom that targets toxins of a specific snake venom is often not as great as the proportion of antibodies in a monovalent antivenom targeting the same venom toxins. Therefore, it can become necessary to administer a greater dose of a polyvalent antivenom than of a monovalent antivenom in order to treat a given envenoming ( 7 , 16). Increasing the dose can, in turn, affect the cost of treatment and the risk of developing adverse reactions to the antivenom (7). Unfortunately, polyvalent antivenoms are favored in many places either due to the lack of monovalent antivenoms or due to the difficulty in choosing which monovalent antivenom to administer in the absence of reliable information on the perpetrating snake species (17).

In addition to enabling the administration of monovalent antivenoms, where available, identifying the offending snake species or the type of venom might enable clinicians to predict and prepare for the development of clinical manifestations. To aid clinicians in this task, there is a common and deceptively simple categorization of elapid venoms as being primarily neurotoxic and viperid venoms as being primarily cytotoxic and/or hemotoxic (here understood as toxicity directed toward blood and the cardiovascular system, including hemostasis) (7). While this simplification does represent a general trend, it can cause clinical misinterpretation and there are several important exceptions to the rule. For example, many major Australian elapid snakes commonly cause coagulopathy, often without evident neurotoxicity, while some important viperids cause minimal cytotoxicity, yet important neurotoxicity (18). Similarly, bites from some elapid species of the cobra genus, particularly spitting cobras, can cause strong cytotoxic symptoms without causing neurotoxicity (19), which may be confused with viper envenomings. Matters are further complicated by the fact that snake venom composition can vary within genera and even within species due to ontogeny and geographical distribution (20-23). As such, the variability of clinical manifestations of envenoming and the time courses of their development complicate the treatment of snakebite (7). Thus, while snakebite is generally well-handled in many areas, room for innovation and improvement still exists. Encouragingly, recent years have seen a renewed interest in such innovations and improvements, with much research being published not only on novel treatment modalities (e.g. recombinant antivenoms and small molecule inhibitors) but also on novel diagnostics (e.g. enzyme-linked immunosorbent assays, lateral flow assays, impedimetric immunoassays, infrared imaging, and polymerase chain reaction-based methods) [see Table 1 and (104-108)]. In time, some of these diagnostic tools may enter the clinic, where they could be utilized to obtain valuable information, such as the identity of the perpetrating snake species or genus, allowing use of monovalent antivenoms, or quantitative measures of the degree of envenoming. Additionally, if implemented in rural settings, diagnostic kits may guide treatment decision for less experienced clinicians, enabling proper management of snakebite victims at rural facilities. This information might support clinical management of snakebite envenoming and epidemiological studies of relevance to antivenom development, resource management, and advocacy for increased attention to snakebite.

\section{COMMONLY ADOPTED APPROACHES FOR DIAGNOSIS OF SNAKEBITE ENVENOMING}

A basic diagnosis of snakebite envenoming requires a thorough patient history, targeted examination, and appropriate laboratory investigations (109). Taking a detailed history includes asking about the circumstances of the bite (e.g. geography, time of the incident, activity, and number of bites), details of the snake (if seen, brought, or photographed), clinical manifestations of envenoming (including time of onset), first aid applied, and past medical history (e.g. allergies, prior snakebites, relevant medications, and pre-existing medical conditions) (109). Laboratory investigations almost always include an evaluation of the blood clotting profile to screen for venom-induced coagulopathies. In its simplest form, a blood clotting test can be carried out in the form of a 20 minute whole blood clotting test (20WBCT). If more sophisticated equipment is available, it is common to run repeated tests of the International Normalized Ratio (INR) of blood clotting, activated partial thromboplastine time (aPTT), D-dimer, and/or fibrinogen degradation products (FDP), supplemented by hemograms and potentially also by electrocardiograms. Acute falls in hemoglobin and hematocrit values may indicate internal bleeding, and a drop in fibrinogen levels might be indicative of coagulopathy $(7,110,111)$. Blood samples are usually also screened for creatine kinase (CK) levels, electrolytes, urea, nitrogen/creatinine, which together with urinalysis (hematuria, proteinuria, urea levels, and urine output) can be used to assess venom-induced rhabdomyolysis and associated complications, such as myoglobinuric renal failure or polyuria, oliguria, or anuria $(110,111)$. See Table 2 for a list of these laboratory investigations. Based on the patient history and laboratory tests, trained toxinologists may be able to infer the offending snake species, and this can in turn guide the choice of treatment.

Diagnostic algorithms summarize much of the knowledge required to diagnose snakebites. They have been developed for some settings and regions to provide support for doctors and other healthcare workers tasked with frontline management of patients with suspected envenoming. Here, it is acknowledged that frontline staffs will often have limited training in managing envenoming and limited rapid access to clinical toxinology expertise to guide their important treatment decisions in the 
TABLE 1 | Overview of snakebite diagnostics capable of differentiating snake venoms.

\begin{tabular}{|c|c|c|c|c|c|c|c|c|c|c|c|}
\hline Type & Subtype & Abs & Area & Snake(s) targeted & LoD & Assay duration & $\begin{array}{l}\text { Tested on } \\
\text { patient } \\
\text { samples? }\end{array}$ & Sample matrix & Notes & Year & Ref. \\
\hline \multirow[t]{13}{*}{$\begin{array}{l}\text { Immuno- } \\
\text { assay }\end{array}$} & $\begin{array}{l}\text { Immuno- } \\
\text { diffusion }\end{array}$ & Equine & & $\begin{array}{l}\text { Cobra spp. (possibly } \\
\text { O. hannah) }\end{array}$ & $\begin{array}{l}\text { 1:100,000,000 } \\
\text { dilution }\end{array}$ & & $\begin{array}{l}\text { Patients: } 1 \\
\text { (case study) }\end{array}$ & Tissue homogenate & & 1957 & (24) \\
\hline & $\begin{array}{l}\text { Immuno- } \\
\text { diffusion }\end{array}$ & $?$ & Australia & $\begin{array}{l}\text { A. antarcticus, } \\
\text { N. scutatus, } \\
\text { P. porphyriacus, } \\
\text { P. textilis }\end{array}$ & $?$ & $>3$ hours & $?$ & $\begin{array}{l}\text { Serum exudate } \\
\text { (guineapig) }\end{array}$ & Only abstract available & 1967 & (25) \\
\hline & $\begin{array}{l}\text { Agglutination } \\
\text { test }\end{array}$ & $\begin{array}{l}\text { Caprine \& } \\
\text { equine }\end{array}$ & California & C. v. helleri & & $>2$ hours & Patients: 16 & Serum & & 1968 & (26) \\
\hline & $\begin{array}{l}\text { Immuno- } \\
\text { diffusion }\end{array}$ & Leporine & Africa & $\begin{array}{l}\text { B. arietans, } \\
\text { C. maculatus, } \\
\text { E. carinatus, } \\
\text { N. haje, } \\
\text { N. melanoleuca, } \\
\text { N. nigricollis }\end{array}$ & & $\begin{array}{l}48 \text { hours } \\
\text { (immuno- } \\
\text { difussion) \& >1 } \\
\text { hour (immuno- } \\
\text { electrophoresis) }\end{array}$ & Patients: 101 & $\begin{array}{l}\text { Wound aspirates, } \\
\text { blister fluids, sera, } \\
\text { urine }\end{array}$ & Sensitivity: $39.6 \%(40 / 101)$ & 1974 & $(27)$ \\
\hline & RIA & & Australia & $\begin{array}{l}\text { N. scutatus, } \\
\text { P. textilis }\end{array}$ & $<10 \mathrm{ng}$ & $>24$ hours & $\begin{array}{l}\text { Patients: } 2 \\
\text { (also tested } \\
\text { on rabbit } \\
\text { serum) }\end{array}$ & Serum, sample buffer & & 1974 & $(28)$ \\
\hline & RIA & & Australia & $\begin{array}{l}\text { N. scutatus, } \\
\text { P. textilis }\end{array}$ & & $>24$ hours & Patients: 3 & $\begin{array}{l}\text { Tissue samples, } \\
\text { fluids }\end{array}$ & & 1975 & (29) \\
\hline & ELISA & $\begin{array}{l}\text { Leporine \& } \\
\text { equine IgGs }\end{array}$ & Multiple & $\begin{array}{l}\text { B. arietans, } \\
\text { C. maculatus, } \\
\text { E. carinatus }\end{array}$ & $1-5 \mathrm{ng} / \mathrm{mL}$ & $\mathrm{O} / \mathrm{N}$ incubation & $\begin{array}{l}\text { No - Tested } \\
\text { in rodents }\end{array}$ & $\begin{array}{l}\text { Serum (human and } \\
\text { rat) }\end{array}$ & $\begin{array}{l}\text { Cross-reactivity to the following species } \\
\text { tested: A. rhodostoma, B. gabonica, C. } \\
\text { adamanteus, E. schistosa, N. haje, N. naja, } \\
\text { N. nigricollis, O. scutellatus, V. berus }\end{array}$ & 1977 & (30) \\
\hline & RIA & Leporine & Australia & N. scutatus & & $\mathrm{O} / \mathrm{N}$ incubation & Patients: 3 & $\begin{array}{l}\text { Urine, serum, } \\
\text { clothing, tissue } \\
\text { samples }\end{array}$ & & 1977 & $\begin{array}{l}(31, \\
32)\end{array}$ \\
\hline & RIA & $\begin{array}{l}\text { Leporine } \\
\text { IgG }\end{array}$ & Australia & $\begin{array}{l}\text { A. antarcticus, } \\
\text { A. superba, } \\
\text { N. scutatus, } \\
\text { O. scutellatus, } \\
\text { P. australis, } \\
\text { P. porphyriacus, } \\
\text { P. textilis }\end{array}$ & $0.1-0.4 \mathrm{ng} / \mathrm{mL}$ & $>20$ hours & Unpublished & Tissue samples & & 1978 & (33) \\
\hline & ELISA & $\begin{array}{l}\text { Leporine } \\
\lg G\end{array}$ & & $?$ & $0.5-2 \mathrm{ng} / \mathrm{mL}$ & 30-90 minutes & $?$ & $?$ & Only abstract available & 1980 & (34) \\
\hline & $\begin{array}{l}\text { Enzyme } \\
\text { immunoassay }\end{array}$ & $\begin{array}{l}\text { Leporine } \\
\text { IgG }\end{array}$ & Australia & $\begin{array}{l}\text { Acantophis spp., } \\
\text { Notechis spp., } \\
\text { Oxyuranus spp., } \\
\text { Pseudoechis spp., } \\
\text { Pseudonaja spp. }\end{array}$ & $5-15 \mathrm{ng} / \mathrm{mL}$ & 20-40 minutes & Patients: 43 & $\begin{array}{l}\text { Whole blood, urine, } \\
\text { wound swab }\end{array}$ & & 1982 & (35) \\
\hline & ELISA & $?$ & $?$ & $?$ & $1 \mathrm{ng} / \mathrm{mL}$ & $>3$ hours & $\begin{array}{l}\text { No - Tested } \\
\text { in rabbits }\end{array}$ & Blood, urine, exudate & Only abstract available & 1983 & (36) \\
\hline & ELISA & $\begin{array}{l}\text { Leporine } \\
\lg G\end{array}$ & $?$ & $\begin{array}{l}\text { A. rhodostoma, } \\
\text { N. naja }\end{array}$ & $7.8-15.6 \mathrm{ng} / \mathrm{mL}$ & 35-45 minutes & Yes & Serum & Only abstract available & 1983 & (37) \\
\hline
\end{tabular}




\begin{tabular}{|c|c|c|c|c|c|c|c|c|c|c|c|}
\hline Type & Subtype & Abs & Area & Snake(s) targeted & LoD & Assay duration & $\begin{array}{l}\text { Tested on } \\
\text { patient } \\
\text { samples? }\end{array}$ & Sample matrix & Notes & Year & Ref. \\
\hline & ELISA & $\begin{array}{l}\text { Leporine } \\
\text { IgG }\end{array}$ & USA & $\begin{array}{l}\text { A. contortrix, } \\
\text { C. atrox, } \\
\text { C. scutulatus }\end{array}$ & $0.1-.01 \mu \mathrm{g} / \mathrm{mL}$ & $\mathrm{O} / \mathrm{N}$ incubation & $\begin{array}{l}\text { No - Tested } \\
\text { in animals }\end{array}$ & $\begin{array}{l}\text { Sero-sanguineous } \\
\text { fluid, blood, urine, } \\
\text { peritoneal fluid, } \\
\text { pleural fluid, lung, } \\
\text { kidney }\end{array}$ & $\begin{array}{l}\text { Cross-reactions with venoms of other } \\
\text { snakes were extensive at higher } \\
\text { concentrations }\end{array}$ & 1984 & (38) \\
\hline & ELISA & Equine & Myanmar & D. russelii & 10 ng/mL & $\mathrm{O} / \mathrm{N}$ incubation & Yes & Serum & $\begin{array}{l}\text { No cross-reactivity found to } B \text {. fasciatus, } N \text {. } \\
\text { naja, O. hannah, } T \text {. gramineus }\end{array}$ & 1984 & (39) \\
\hline & ELISA & Leporine & Thailand & N. kaouthia & 2 ng/well & & Yes & Serum & & 1986 & $(40)$ \\
\hline & $\begin{array}{l}\text { Enzyme- } \\
\text { linked } \\
\text { coagulation } \\
\text { assay }\end{array}$ & $\begin{array}{l}\text { Murine } \\
\text { monoclonal } \\
\lg G\end{array}$ & & D. russelii & $2-10 \mathrm{pg} / \mathrm{mL}$ & & No & & & 1987 & (41) \\
\hline & ELISA & & Nigeria & $\begin{array}{l}\text { B. arietans, } \\
\text { C. maculatus, } \\
\text { E. carinatus }\end{array}$ & & $\mathrm{O} / \mathrm{N}$ incubation & Patients: 31 & $\begin{array}{l}\text { Blood, serum, urine, } \\
\text { sputum, bite site } \\
\text { aspirates }\end{array}$ & & 1987 & $(42)$ \\
\hline & ELISA & & Philippines & N. n. philippinensis & & $\mathrm{O} / \mathrm{N}$ incubation & $\begin{array}{l}\text { Patients: } 1 \\
\text { (postmortem) }\end{array}$ & Blood & & 1987 & (43) \\
\hline & ELISA & $\begin{array}{l}\text { Leporine } \\
\lg G\end{array}$ & Thailand & $\begin{array}{l}\text { C. rhodostoma, } \\
\text { D. russelii, } \\
\text { N. kaouthia, } \\
\text { T. albolabris }\end{array}$ & $10-20 \mathrm{ng} / \mathrm{mL}$ & $\mathrm{O} / \mathrm{N}$ incubation & Patients: 251 & Serum & & 1987 & $(44)$ \\
\hline & RIA & $\begin{array}{l}\text { Murine } \\
\text { monoclonal } \\
\text { Abs }\end{array}$ & Thailand & D. russelii & $\begin{array}{l}4-20 \mathrm{ng} / \mathrm{mL} \\
\text { depending on } \\
\text { matrix }\end{array}$ & $\mathrm{O} / \mathrm{N}$ incubation & Patients: 4 & Serum, urine & Known to cross-react with cobra venom. & 1987 & $(45)$ \\
\hline & ELISA & Equine & Europe & V. ammodytes & $<1 \mathrm{ng} / \mathrm{mL}$ & $<20$ minutes & $\begin{array}{l}\text { No - Tested } \\
\text { in rabbits }\end{array}$ & Blood & Specificity mentioned as being a problem. & 1988 & $(46)$ \\
\hline & ELISA & $?$ & Asia & A. b. blomhoffii & 5.4 ng/well & $?$ & $\begin{array}{l}\text { No - Tested } \\
\text { in mice }\end{array}$ & Serum & $\begin{array}{l}\text { Only abstract available. No cross-reactivity } \\
\text { to R. t. tigrinus venom. }\end{array}$ & 1988 & $(47)$ \\
\hline & ELISA & $\begin{array}{l}\text { Leporine } \\
\lg G\end{array}$ & Brazil & B. jararaca & $14.6 \mathrm{ng} / \mathrm{mL}$ & $\mathrm{O} / \mathrm{N}$ incubation & $\begin{array}{l}\text { No - Tested } \\
\text { in mice }\end{array}$ & Serum & $\begin{array}{l}\text { Tested for cross-reactivity to Bothrops spp., } \\
\text { Crotalus spp., Lachesis spp., and Tityus } \\
\text { serrulatus venom. }\end{array}$ & 1990 & $(48)$ \\
\hline & ELISA & $?$ & $?$ & A. b. blomhoffii & $?$ & $?$ & $\begin{array}{l}\text { No - Tested } \\
\text { in rats \& } \\
\text { rabbits }\end{array}$ & Serum & Only abstract available & 1990 & $(49)$ \\
\hline & $\begin{array}{l}\text { Agglutination } \\
\text { test }\end{array}$ & $\begin{array}{l}\text { Leporine } \\
\lg G\end{array}$ & Thailand & $\begin{array}{l}\text { B. fasciatus, } \\
\text { C. rhodostoma, } \\
\text { D. russelii, } \\
\text { N. kaouthia, } \\
\text { N. n. siamensis, } \\
\text { O. hannah, } \\
\text { T. albolabris }\end{array}$ & $0.16-1.2 \mu \mathrm{g} / \mathrm{mL}$ & 40 minutes & $\begin{array}{l}\text { Serum } \\
\text { samples: } 59 \\
\text { Wound } \\
\text { swabs: } 26\end{array}$ & $\begin{array}{l}\text { Serum, wound } \\
\text { swabs }\end{array}$ & $\begin{array}{l}\text { Sensitivity of } 52.5 \% \text {. Tested for hook effect } \\
\text { and interference from sample matrices. }\end{array}$ & 1991 & $(50)$ \\
\hline & ELISA & $\begin{array}{l}\text { Equine F } \\
\left(a b^{\prime}\right)_{2}\end{array}$ & Brazil & C. d. terrificus & $1-3 \mathrm{pg} / \mathrm{mL}$ & $\mathrm{O} / \mathrm{N}$ incubation & $\begin{array}{l}\text { No - Tested } \\
\text { in mice }\end{array}$ & $\begin{array}{l}\text { Serum (mice), } \\
\text { sample buffer }\end{array}$ & & 1991 & $(51)$ \\
\hline & ELISA & $\begin{array}{l}\text { Leporine } \\
\lg G\end{array}$ & Myanmar & D. russelii & $10 \mathrm{ng} / \mathrm{mL}$ & $\mathrm{O} / \mathrm{N}$ incubation & $\begin{array}{l}\text { Patients: } 311 \\
\text { Controls: } 118\end{array}$ & Serum & $\begin{array}{l}\text { Specificity } 88 \% \text { ( } 14 \text { false positives } \\
\text { from } 118 \text { negatives). Tested for }\end{array}$ & 1991 & (52) \\
\hline
\end{tabular}




\begin{tabular}{|c|c|c|c|c|c|c|c|c|c|c|c|}
\hline Type & Subtype & Abs & Area & Snake(s) targeted & LoD & Assay duration & $\begin{array}{l}\text { Tested on } \\
\text { patient } \\
\text { samples? }\end{array}$ & Sample matrix & Notes & Year & Ref. \\
\hline & & & & & & & & & $\begin{array}{l}\text { cross-reactivity to B. fasciatus, } \\
\text { N. kaouthia, } \\
\text { O. hannah, } \\
\text { T. erythrurus. }\end{array}$ & & \\
\hline & ELISA & $\begin{array}{l}\text { Equine } \mathrm{F} \\
\left(\mathrm{ab}^{\prime}\right)_{2}\end{array}$ & Europe & Vipera spp. & $\begin{array}{l}2-7 \mathrm{ng} / \mathrm{mL} \\
\text { (depending on } \\
\text { sample matrix) }\end{array}$ & $>4.5$ hours & Yes & Blood, serum, urine & $\begin{array}{l}\text { Tested for cross-reactivity to } \\
\text { B. jararaca and C. d. terrificus. }\end{array}$ & 1992 & $\begin{array}{l}(53- \\
56)\end{array}$ \\
\hline & ELISA & $\begin{array}{l}\text { Leporine } \\
\lg G\end{array}$ & Australia & $\begin{array}{l}\text { A. antarcticus, } \\
\text { N. scutatus, } \\
\text { O. scutellatus, } \\
\text { P. australis, } \\
\text { P. textilis. }\end{array}$ & $2.5 \mathrm{ng} / \mathrm{mL}$ & $\mathrm{O} / \mathrm{N}$ incubation & Unpublished & Sample buffer & & 1992 & $(57)$ \\
\hline & & $\begin{array}{l}\text { Leporine } \\
\text { lgG }\end{array}$ & $\begin{array}{l}\text { Southern } \\
\text { Thailand }\end{array}$ & C. rhodostoma & $5 \mathrm{ng} / \mathrm{mL}$ & 50 minutes & No & Sample buffer & Cross-reactivity to 26 venoms tested. & 1992 & $(58)$ \\
\hline & $\begin{array}{l}\text { Agglutination } \\
\text { test }\end{array}$ & $\begin{array}{l}\text { Leporine } \\
\lg G\end{array}$ & Thailand & $\begin{array}{l}\text { B. fasciatus, } \\
\text { C. rhodostoma, } \\
\text { D. russelli, } \\
\text { N. kaouthia, } \\
\text { O. hannah, } \\
\text { T. albolabris }\end{array}$ & $2-635 \mathrm{ng} / \mathrm{mL}$ & $60-120$ minutes & $\begin{array}{l}\text { Serum } \\
\text { samples: } 59 \\
\text { Wound } \\
\text { swabs: } 26\end{array}$ & Serum, wound swab & $\begin{array}{l}\text { Sensitivity of } 81.3 \% \text { for serum samples and } \\
61.5 \% \text { for wound swabs. Cross reactivity at } \\
\text { concentrations at least } 62 \text { times higher. }\end{array}$ & 1993 & (59) \\
\hline & ELISA & $\begin{array}{l}\text { Leporine } \\
\operatorname{lgG}\end{array}$ & Brazil & $\begin{array}{l}\text { B. alternatus, } \\
\text { B. atrox, } \\
\text { B. jararaca, } \\
\text { B.jararacussu, } \\
\text { B. moojeni, } \\
\text { B. neuwedi, } \\
\text { C. d. terrificus, } \\
\text { C. d. collineatus, } \\
\text { L. muta }\end{array}$ & $<0.01-0.1 \mu \mathrm{g} / \mathrm{mL}$ & $\mathrm{O} / \mathrm{N}$ incubation & No & $\begin{array}{l}\text { Sample buffer, serum } \\
\text { (non-envenomed } \\
\text { humans) }\end{array}$ & & 1993 & (60) \\
\hline & ELISA & $\begin{array}{l}\text { Leporine } \\
\text { IgG }\end{array}$ & Brazil & $\begin{array}{l}\text { B. atrox, } \\
\text { L. m. muta }\end{array}$ & $20 \mathrm{ng} / \mathrm{mL}$ & 2 hours & Yes & Serum & Also tested in mice. & 1993 & (61) \\
\hline & $\begin{array}{l}\text { Fluorogenic } \\
\text { ELISA }\end{array}$ & $?$ & & D. russelii & $0.1 \mathrm{pg} / \mathrm{mL}$ & $?$ & $?$ & $?$ & $\begin{array}{l}\text { Only abstract available. Shown to cross- } \\
\text { react with several other venoms. }\end{array}$ & 1993 & (62) \\
\hline & ELISA & & $\begin{array}{l}\text { Papua } \\
\text { New } \\
\text { Guinea }\end{array}$ & P. papuanus & & $\mathrm{O} / \mathrm{N}$ incubation & Patients: 9 & $\begin{array}{l}\text { Serum, urine, wound } \\
\text { aspirates }\end{array}$ & & 1994 & (63) \\
\hline & ELISA & $\begin{array}{l}\text { Leporine } \\
\lg G\end{array}$ & Tunisia & E. pyramidum & $<10 \mathrm{ng} / \mathrm{mL}$ & $\mathrm{O} / \mathrm{N}$ & Yes & Serum & & 1994 & (64) \\
\hline & ELISA & & $\begin{array}{l}\text { North } \\
\text { America }\end{array}$ & Agkistrodon spp. & $2 \mathrm{ng} / \mathrm{mL}$ & $>5$ hours & $\begin{array}{l}\text { No - Tested } \\
\text { in rabbits }\end{array}$ & Serum & & 1994 & (65) \\
\hline & ELISA & & Myanmar & O. hannah & $<20 \mathrm{ng} / \mathrm{mL}$ & & $\begin{array}{l}\text { Patients: } 2 \\
\text { (case } \\
\text { studies) }\end{array}$ & Serum & & 1995 & (66) \\
\hline & ELISA \& RIA & Ovine Fab & Europe & Vipera spp. & $\begin{array}{l}0.8 \mathrm{ng} / \mathrm{mL} \text { (ELISA) } \\
\& 2 \mathrm{ng} / \mathrm{mL}(\mathrm{RIA})\end{array}$ & $\begin{array}{l}>3 \text { hours }(E \sqcup S A) \& \\
\text { O/N incubation (RIA) }\end{array}$ & Yes & Plasma, urine & & 1996 & (67) \\
\hline & ELISA & $\begin{array}{l}\text { Leporine F } \\
\left(\mathrm{ab}^{\prime}\right)_{2}\end{array}$ & India & $\begin{array}{l}\text { B. caerulus, } \\
\text { D. russelii, }\end{array}$ & $1 \mathrm{ng} / \mathrm{mL}$ & $30 \mathrm{~min}$ & Patients: 27 & $\begin{array}{l}\text { Blood, serum, urine, } \\
\text { wound swab }\end{array}$ & Only abstract available & 1996 & (68) \\
\hline
\end{tabular}




\begin{tabular}{|c|c|c|c|c|c|c|c|c|c|c|c|}
\hline Type & Subtype & Abs & Area & Snake(s) targeted & LoD & Assay duration & $\begin{array}{l}\text { Tested on } \\
\text { patient } \\
\text { samples? }\end{array}$ & Sample matrix & Notes & Year & Ref. \\
\hline & & & & $\begin{array}{l}\text { E. carinatus, } \\
\text { N. naja }\end{array}$ & & & & & & & \\
\hline & ELISA & $\begin{array}{l}\text { Equine } F \\
\left(a b^{\prime}\right)_{2}\end{array}$ & Martinique & B. lanceolatus & & 3 hours & $\begin{array}{l}\text { Patients: } 40 \\
\text { Controls: } \\
120\end{array}$ & Serum & Sensitivity $46 \%$, specificity $88 \%$. & 1997 & (69) \\
\hline & $\begin{array}{l}\text { ELISA \& } \\
\text { agglutination } \\
\text { assay }\end{array}$ & Equine & $\begin{array}{l}\text { Central } \\
\text { America }\end{array}$ & Micrurus spp. & $\begin{array}{l}0.3 \mathrm{mg} / \mathrm{mL} \\
\text { (agglutination } \\
\text { assay) \& } 4 \mathrm{ng} / \mathrm{mL} \\
\text { (ELISA) }\end{array}$ & $\begin{array}{l}>5 \text { minutes } \\
\text { (agglutination } \\
\text { test) \& O/N } \\
\text { incubation } \\
\text { (ELISA) }\end{array}$ & $\begin{array}{l}\text { No - Tested } \\
\text { in rabbits } \\
\text { and mice }\end{array}$ & Serum, plasma & & 1997 & (70) \\
\hline & ELISA & $\begin{array}{l}\text { Caprine \& } \\
\text { leporine } \lg G\end{array}$ & India & $\begin{array}{l}\text { Bungarus spp., } \\
\text { Daboia spp., } \\
\text { Echis spp., } \\
\text { Naja spp. }\end{array}$ & $0.1 \mathrm{ng} / \mathrm{mL}$ & $>5$ hours & $\begin{array}{l}\text { Yes } \\
\text { (postmortem } \\
\text { only) }\end{array}$ & Tissue samples & & 1999 & (71) \\
\hline & ELISA & $?$ & Taiwan & Cobra spp. & $0.5 \mathrm{ng} / \mathrm{mL}$ & 6 hours & $?$ & $\begin{array}{l}\text { Calf serum and } \\
\text { human urine }\end{array}$ & Only abstract available & 2002 & $(72)$ \\
\hline & $\begin{array}{l}\text { Optical } \\
\text { immunoassay }\end{array}$ & $\begin{array}{l}\text { Leporine } \\
\lg G\end{array}$ & Asia & B. multicinctus & $2.5-10 \mathrm{ng} / \mathrm{mL}$ & 25 minutes & $\begin{array}{l}\text { No - Tested } \\
\text { in mice }\end{array}$ & $\begin{array}{l}\text { Blood, tissue } \\
\text { samples }\end{array}$ & $\begin{array}{l}\text { Cross-reactivity to } 11 \text { venoms and toxins } \\
\text { tested. }\end{array}$ & 2002 & (73) \\
\hline & $\begin{array}{l}\text { Agglutination } \\
\text { test }\end{array}$ & Equine & Venezuela & $\begin{array}{l}\text { Bothrops spp., } \\
\text { Crotalus spp. }\end{array}$ & $167 \mu \mathrm{g} / \mathrm{mL}$ & 10 minutes & No & Sample buffer & LoD unit uncertain. & 2004 & $(74)$ \\
\hline & $\begin{array}{l}\text { Optical } \\
\text { immunoassay }\end{array}$ & $\begin{array}{l}\text { Leporine } \\
\lg G\end{array}$ & Vietnam & $\begin{array}{l}\text { C. rhodostoma, } \\
\text { N. kaouthia, } \\
\text { O. hannah, } \\
\text { T. albolabris }\end{array}$ & $\begin{array}{l}0.2-0.8 \mathrm{ng} / \mathrm{mL} \\
\text { depending on the } \\
\text { venom and } \\
\text { sample matrix }\end{array}$ & 40 minutes & $\begin{array}{l}\text { Patients: } 83 \\
\text { Samples: } \\
125\end{array}$ & $\begin{array}{l}\text { Serum, urine, wound } \\
\text { exudate }\end{array}$ & & 2004 & $(75)$ \\
\hline & ELISA & $\begin{array}{l}\text { Avian } \lg Y \& \\
\text { leporine } \lg G\end{array}$ & India & N. naja & $0.1-300 \mathrm{ng}$ & $\mathrm{O} / \mathrm{N}$ incubation & $\begin{array}{l}\text { Patients: } 12 \\
\text { (live) } \\
\text { Patients: } 7 \\
\text { (postmortem) }\end{array}$ & $\begin{array}{l}\text { Skin, blood, } \\
\text { cerebrospinal fluid }\end{array}$ & & 2006 & (76) \\
\hline & ELISA & $\begin{array}{l}\text { Leporine } \\
\operatorname{lgG}\end{array}$ & India & $\begin{array}{l}\text { B. caeruleus, } \\
\text { N. naja }\end{array}$ & & $\mathrm{O} / \mathrm{N}$ incubation & $\begin{array}{l}\text { Samples: } 22 \\
\text { (postmortem) }\end{array}$ & Skin, blood & & 2007 & $(77)$ \\
\hline & $\begin{array}{l}\text { Immuno- } \\
\text { flourescence }\end{array}$ & & & N. kaouthia & $5-10 \mathrm{ng} / \mathrm{mL}$ & 3 hours & No & Sample buffer & & 2008 & $(78)$ \\
\hline & ELISA & $\begin{array}{l}\text { Leporine } \\
\lg G\end{array}$ & Australasia & Oxyuranus spp. & $0.15 \mathrm{ng} / \mathrm{mL}$ & $\mathrm{O} / \mathrm{N}$ incubation & Patients: 17 & Serum & $\begin{array}{l}\text { Also tested in rat serum and for cross- } \\
\text { reactivity with Australian snake venoms. }\end{array}$ & 2010 & (79) \\
\hline & ELISA & $\begin{array}{l}\text { Leporine } \\
\text { lgG }\end{array}$ & Colombia & L. acrochorda & $3.9 \mathrm{ng} / \mathrm{mL}$ & & No & Sample buffer & Specificity $100 \%$. & 2012 & (80) \\
\hline & ELISA & $\begin{array}{l}\text { Leporine } \\
\text { lgG }\end{array}$ & Egypt & $\begin{array}{l}\text { N. haje, } \\
\text { N. nigricollis, } \\
\text { W. aegyptia }\end{array}$ & $<10$ ng/well & $\mathrm{O} / \mathrm{N}$ incubation & No & Sample buffer & $\begin{array}{l}\text { Avidities of 2.5-2.8 depending on the } \\
\text { venom }\end{array}$ & 2013 & (81) \\
\hline & LFA & Avian & Taiwan & N. atra & $5 \mathrm{ng} / \mathrm{mL}$ & 20 minutes & $\begin{array}{l}\text { Patients: } 88 \\
\text { (34 cobra } \\
\text { and } 54 \text { non- } \\
\text { cobra) }\end{array}$ & Serum & Sensitivity $83.3 \%$, specificity $100 \%$. & 2014 & (82) \\
\hline & LFA & $\begin{array}{l}\text { Equine \& } \\
\text { leporine } \lg G\end{array}$ & India & Daboia spp., Naja spp. & $0.1 \mathrm{ng} / \mathrm{mL}$ & 10 minutes & $\begin{array}{l}\text { No - Tested } \\
\text { in mice }\end{array}$ & Plasma & & 2016 & (83) \\
\hline & ELISA & $\begin{array}{l}\text { Leporine } \\
\lg G\end{array}$ & India & $\begin{array}{l}\text { Bungarus spp., } \\
\text { Daboia spp., }\end{array}$ & $1 \mathrm{ng} / \mathrm{mL}$ & 20-25 minutes & $\begin{array}{l}\text { No - Tested } \\
\text { in mice }\end{array}$ & Sample buffer & & 2017 & (84) \\
\hline
\end{tabular}




\begin{tabular}{|c|c|c|c|c|c|c|c|c|c|c|c|}
\hline Type & Subtype & Abs & Area & Snake(s) targeted & LoD & Assay duration & $\begin{array}{l}\text { Tested on } \\
\text { patient } \\
\text { samples? }\end{array}$ & Sample matrix & Notes & Year & Ref. \\
\hline & & & & $\begin{array}{l}\text { Echis spp., } \\
\text { Naja spp. }\end{array}$ & & & & & & & \\
\hline & ELISA \& LFA & Equine & Taiwan & $\begin{array}{l}\text { Neurotoxic vs } \\
\text { hemorrhagic venom }\end{array}$ & $\begin{array}{l}\text { LoD of } 5-50 \mathrm{ng} / \\
\mathrm{mL}(\mathrm{LFA}) \& \mathrm{LOQ} \\
\text { of } 0.39-0.78 \mathrm{ng} / \\
\mathrm{mL}(\mathrm{ELISA})\end{array}$ & $10-15$ minutes & Patients: 21 & Serum & $\begin{array}{l}\text { Sensitivity and specificity of } 100 \% \text { for } \\
\text { neurotoxic venoms. Sensitivity of } 36.4 \% \text { for } \\
\text { hemorrhagic venoms. }\end{array}$ & 2018 & (85) \\
\hline & $\begin{array}{l}\text { Impedimetric } \\
\text { immunoassay }\end{array}$ & Equine & Brazil & Bothrops spp. & $0.27 \mathrm{ug} / \mathrm{mL}$ & $>25$ minutes? & No & Sample buffer & $\begin{array}{l}\text { Tested for cross-reactivity to } C . d \text {. terrificus } \\
\text { and } M \text {. leminiscatus. }\end{array}$ & 2018 & (86) \\
\hline & ELISA & Leporine & Sri Lanka & $\begin{array}{l}\text { B. caeruleus, } \\
\text { D. russelii, } \\
\text { H. hypnale, } \\
\text { N. naja }\end{array}$ & $\begin{array}{l}0.19-1.56 \mathrm{ng} / \mathrm{mL} \\
\text { (depending on } \\
\text { the venom) }\end{array}$ & $>2$ hours & $\begin{array}{l}\text { Patients: } 19 \\
\text { Controls: } 20\end{array}$ & Serum & $\begin{array}{l}\text { Quantitative. Cross-reactivity between the } \\
\text { venoms was tested. }\end{array}$ & 2020 & (87) \\
\hline & LFA & $\begin{array}{l}\text { Avian \& } \\
\text { equine }\end{array}$ & $\begin{array}{l}\text { South- } \\
\text { East Asia }\end{array}$ & $\begin{array}{l}\text { Daboia spp., } \\
\text { Naja spp. }\end{array}$ & $\begin{array}{l}10 \mathrm{ng} / \mathrm{mL} \text { (in } \\
\text { vitro) }\end{array}$ & 25-30 minutes & Samples: 5 & Serum & & 2020 & (88) \\
\hline & LFA & $\begin{array}{l}\text { Leporine \& } \\
\text { equine }\end{array}$ & $\begin{array}{l}\text { Asia \& } \\
\text { Africa }\end{array}$ & Naja spp. & $\begin{array}{l}5-10 \mathrm{ng} / \mathrm{mL} \text { for } \\
\text { Asian cobras and } \\
<500 \mathrm{ng} / \mathrm{mL} \text { for } \\
\text { African cobras }\end{array}$ & $>20$ minutes & No & Serum (fetal bovine) & Based on (82). & 2020 & (89) \\
\hline \multirow[t]{3}{*}{$\begin{array}{l}\text { Molecular } \\
\text { biology }\end{array}$} & PCR & $\mathrm{N} / \mathrm{A}$ & Thailand & N. kaouthia & & $>2$ hours & $\begin{array}{l}\text { No - Tested } \\
\text { on mice }\end{array}$ & Wound swabs (mice) & $\begin{array}{l}\text { Also tested on venom from } B \text {. fasciatus, } C \text {. } \\
\text { rhadostma, D. russelii, O. Hannah. }\end{array}$ & 2001 & (90) \\
\hline & PCR & $N / A$ & Thailand & $\begin{array}{l}\text { B. fasciatus, } \\
\text { C. rhodostoma, } \\
\text { D. siamensis, } \\
\text { Hydrophiinae spp., } \\
\text { Naja spp., } \\
\text { O. Hannah, } \\
\text { Trimeresurus spp. }\end{array}$ & $0.025 \mathrm{ng} / \mathrm{mL}$ & $>67$ minutes & No & Saliva (snake) & & 2015 & (91) \\
\hline & PCR & N/A & Nepal & $\begin{array}{l}\text { Bungarus spp., } \\
\text { Naja spp., } \\
\text { O. hannah, } \\
\text { O. moticola, } \\
\text { Trimeresurus spp. }\end{array}$ & & $\mathrm{O} / \mathrm{N}$ incubation & Patients: 565 & Wound swab & Specificity $100 \%$. & 2016 & (92) \\
\hline \multirow[t]{3}{*}{ Misc. } & $\begin{array}{l}\text { Enzymatic } \\
\text { activity assay }\end{array}$ & $\mathrm{N} / \mathrm{A}$ & $\begin{array}{l}\text { Sri Lanka } \\
\& \text { Australia }\end{array}$ & $\begin{array}{l}\text { B. caeruleus, } \\
\text { D. russelii, } \\
\text { H. hypnale, } \\
\text { N. naja, } \\
\text { P. porphyriacus }\end{array}$ & & & Patients: 108 & Serum & & 2014 & (93) \\
\hline & $\begin{array}{l}\text { Infrared } \\
\text { thermography }\end{array}$ & N/A & Brazil & $\begin{array}{l}\text { B. moojeni, } \\
\text { C. d. terrificus, } \\
\text { B. jararaca }\end{array}$ & & $>15$ minutes & Patients: 8 & & & 2017 & (94) \\
\hline & $\begin{array}{l}\text { Enzymatic } \\
\text { activity assay } \\
\& \text { ELISA }\end{array}$ & $\mathrm{N} / \mathrm{A}$ & Australia & Elapid spp. & $\begin{array}{l}0.1-0.2 \mathrm{ng} / \mathrm{mL} \\
\text { (ELISA) }\end{array}$ & & $\begin{array}{l}\text { Patients: } 115 \\
\text { Controls: } 80\end{array}$ & Serum & & 2018 & (95) \\
\hline
\end{tabular}


TABLE 2 | Examples of auxilliary tests that are frequently performed for suspected snakebite victims.

\begin{tabular}{ll}
\hline \multicolumn{1}{c}{ Auxilliary tests } \\
\hline Type & \multicolumn{1}{c}{ Subtype } \\
\hline Hemograms & Platelet count \\
& Blood count (hemoglobin, white cell count, absolute \\
& lymphocyte count) \\
& Examination of blood film for evidence of intravascular \\
& hemolysis (schistocytes, spherocytes, etc.) \\
Clotting profile & Fibrinogen level \\
& Prothrombin time/INR of blood clotting \\
& Activated partial thromboplastine time (aPTT) \\
& D-dimer/fibrinogen degradation products (FDP) \\
Electrolytes \\
biochemistry & Bilirubin \\
& Liver function tests \\
& Creatine kinase (CK; CPK) \\
& Hematuria \\
Urinalysis & Myoglobinuria \\
Renal function & Serum creatinine \\
& Urea \\
& Glomerular filtration rate \\
Uline output (polyuria, oliguria, anuria) & \\
\hline &
\end{tabular}

critical early hours after a bite. The purpose of such diagnostic algorithms is to synthesize and distill the knowledge and experience of experts in clinical toxinology into a readily and rapidly accessible format to guide less experienced health professionals toward optimal care of bitten and envenomed patients. Formally assessing the effectiveness of diagnostic and treatment algorithms for envenoming is a challenge, with no clear published research available. However, experience in countries such as Australia (first world) and Myanmar (developing world) appears to indicate that diagnostic algorithms developed for snakebite, individualized for each country or region, are both widely used and accepted. In Myanmar, snakebite diagnostic algorithms were developed by a team of health professionals through a series of drafts, tested by frontline healthcare workers, and a final version was adopted and rolled out nationally by the Ministry of Health. Feedback from frontline healthcare workers in Myanmar was strongly positive. Diagnostic algorithms do not replace expertise in clinical toxinology, but can be an important part of an optimal care pathway. However, it must always be acknowledged in such algorithms that they are merely a guide and cannot cater for every possible clinical scenario and presentation.

As previously mentioned, it is also a common procedure to ask whether the patient saw the snake, and if so, what it looked like (112). However, using the victim's description of the snake is often not, in isolation, a reliable diagnostic method for identifying the snake, although for some snakes in some countries (e.g. Russell's viper in Myanmar) it may be reasonably reliable. In some cases, the biting snake is not seen, and even if it has been spotted, the victim's description can potentially be misleading (113). While it may be easier to identify the snake if it is brought to the hospital for identification, even in these cases, misidentification can occur, and in some communities, there is an unwillingness among hospital staff to inspect or handle the snake (114). As an example, hump-nosed pit vipers (H. hypnale) are often misidentified as saw-scaled vipers (E. carinatus) in India, resulting in administration of ineffective antivenom (115). Even if the snake has been positively identified by an expert herpetologist, the clinical presentation of the patient is pivotal, as different specimens of venomous snakes (e.g. from different regions) can cause different clinical envenoming syndromes $(109,116)$. Another caveat of this approach is the inherent risk of attempting to capture or kill the snake, which can lead to further envenoming of the victim or a helper attempting to catch the snake; however, if a snake has already been killed, this is a potentially valuable diagnostic aid. Hospital staff should be encouraged to examine and preserve all such presented snakes, as this can allow retrospective studies clearly defining medically relevant species for a particular region. In most settings, $70 \%$ ethanol is an appropriate preservative for dead snakes, immersing the entire snake and injecting the preserving fluid into the body cavity. It is critically important that preserved snakes are adequately labeled and that preservation methods that will not lead to deterioration of the label (in the preserving fluid) are employed, so that subsequent examination can unequivocally link the dead snake to a particular snakebite patient.

\section{SNAKEBITE DIAGNOSIS IN AUSTRALIA}

In Australia, snakebites are diagnosed based on patient history and laboratory investigations, as described above. In combination with neurological assessment, it is possible to identify most severe envenoming cases within 12 hours of the bite (117), after which patients with confirmed or suspected envenoming can be discharged if clinical findings and laboratory test results indicate no envenoming has occurred. In rare cases, envenoming - in particular by death adders does not manifest itself before 24 hours post-bite, though it is unclear whether such late-presenting envenomings can progress to severe or life-threatening envenomings in subsequent hours.

Precise epidemiological data on snakebites in Australia are not available; however, one estimate suggests between 500 and 3,000 snakebites occur annually (118), while another study reported 6,123 hospital admissions due to contact with venomous snakes in a period from August 2001 to May 2013, or an average of about 500 cases per year (119). Snakebite envenoming in Australia is not common, but can be severe with an average of 2.2 deaths annually in the past 15 years with out-of-hospital cardiac arrest being the most common cause (120, 121). Most medically significant snakebites can be attributed to five terrestrial snake groups: Brown snakes (Pseudonaja spp.), members of the tiger snake group (Notechis scutatus, Tropidechis carinatus, Austrelaps spp., and Hoplocephalus spp.), black snakes and mulga snakes (Pseudechis spp.), taipans (Oxyuranus spp.), and death adders (Acanthophis spp.) $(18,109,121)$. Some of these snakes can easily be confused by people without experience in identifying snakes. For example, a snakebite victim may report to have been bitten by "a brown snake", which could belong to any number of 
species, e.g. the eastern brown snake (Pseudonaja textilis) or the king brown snake (Pseudoechis australis) (see Figures 1A, B), the clinical significance and treatment of which would differ. Diagnostic algorithms can aid clinicians in determining the snake species most likely to have caused the bite, as exemplified in Figure $2(109,116)$.

Major local effects, such as hemorrhagic blebs and necrosis after snakebites, are rare in Australia and minimal for the brown snakes that cause most cases of snakebite. Nonetheless, some species may cause at least moderate local swelling, and local bruising can uncommonly occur following bites by those species causing defibrination coagulopathy (116). Systemic effects vary depending on species and may include neurotoxic flaccid descending paralysis, systemic myolysis, defibrination coagulopathy, anticoagulant coagulopathy, acute kidney injury (AKI), sudden collapse, cardiac collapse/arrest, anaphylaxis, and microangiopathic hemolytic anemia (MAHA) $(109,116)$. Death adders, taipans, tiger snakes, and the rough scaled snake commonly cause neurotoxicity; however, tiger snakes, the rough scaled snake, and taipans can also cause myotoxicity. Black snakes and mulga snakes cause myotoxicity and anticoagulant coagulopathy, while defibrination coagulopathy (referred to by some authors as "venom-induced consumption coagulopathy", "VICC") is frequent for brown snakes, tiger snakes, rough scaled snake, broad headed snakes (Hoplocephalus spp.), and taipans (116). Defibrination coagulopathy can be diagnosed based on an elevated INR of blood clotting and aPTT and grossly elevated D-dimer; the latter may be the first evidence of developing coagulopathy, before any changes in INR of blood clotting and aPTT occur (109). In case of anticoagulant coagulopathy, fibrinogen and degradation products are at normal levels, and aPTT and possibly INR of blood clotting can be prolonged/elevated, whereas defibrination coagulopathy leads to decreased or undetectable levels of fibrinogen and elevated levels of degradation products, both Ddimer and FDP $(109,116)$. Typically, symptoms of coagulopathy are seen early, sometimes upon arrival to the emergency department, while neurotoxicity and myotoxicity take hours to develop with CK levels peaking between 24-48 hours after the bite (116).

If severe envenoming is diagnosed, diagnostic algorithms in conjunction with the Seqirus (formerly Commonwealth Serum Labs, CSL) Snake Venom Detection Kit (SVDK) can help determine which snake venom immunotype is involved (109). The SVDK is a non-laboratory, rapid, freeze-dried, immunoassay kit, developed for Australian and some Papua New Guinea snake venoms, that uses bite site swabs, or alternatively a urine sample, to detect the venom immunotype. The SVDK is widely distributed and available in Australia, but its usage has declined, in part because of concerns over accuracy and reliability. The reliability of the SVDK is debated due to a high risk of false positives when the SVDK is inappropriately tested on non-envenomed patients, the occurrence of false negatives with envenomed patients (121), and the presence of a hook effect (also known as prozone effect - an effect which describes how the measured analyte concentration can decrease even as the actual concentration increases) (122). The propensity for false positives has proven especially problematic, as the SVDK has frequently been used inappropriately for all suspected snakebites, sometimes as a screening tool - a function that it was not designed for and is not suitable for. One study suggests that false negatives are often a result of operator errors (123), and perhaps for this reason, there is now an annual quality assurance process for all laboratories using the SVDK to minimize the likelihood of operator errors. Antivenom is available at 750 hospitals across Australia, and if an immunotype can be determined via the SVDK or otherwise, the appropriate "monovalent" antivenom can be selected as treatment (109). In addition to the five terrestrial "monovalent" antivenoms, a polyvalent antivenom against the five snake groups is also available (121). If the diagnostic algorithms and the SVDK results are in conflict, then either polyvalent antivenom or an appropriate mixture of two "monovalent" antivenoms should be used, but the large volume of antivenom needed, particularly if using polyvalent, represents a potential increased risk of adverse reactions $(7,109)$. If a clinician is in doubt when handling suspected or confirmed snakebite cases, then advice may be sought via the antivenom producer (Seqirus, Melbourne) or through the Clinical Toxinology service (Women's \& Children's Hospital, Adelaide) (109).

From 2005 to 2015 , the median dose of antivenom administered to Australian snakebite victims has decreased from four vials to one vial, with debated implications for treatment $(121,124)$. Meanwhile, the median time to first antivenom administration has remained unchanged at 4.3 hours (121), despite increasing evidence of a more favorable outcome when antivenom is administered early $(125,126)$. This lack of change in time to antivenom administration might be because Australia covers a large landmass, with many areas being remote from major health services, making delays in treating snakebites more likely to occur, particularly in remote sites, where antivenom is not stocked and aeromedical retrieval is required. Competing demands on aeromedical retrieval services can exacerbate delays. Additionally, many dangerously venomous snakes in Australia only cause envenoming in a minority of cases. As prophylactive antivenom administration can negatively affect the patient, antivenom should not be administered until it is certain that the patient has been envenomed; this can necessitate further delays in antivenom administration as symptom development is monitored. For these reasons, it seems unlikely that the time to antivenom administration will improve significantly in Australia.

\section{SNAKEBITE DIAGNOSIS IN ASIA}

The epidemiology of snakebite envenoming differs across Asia as a result of high inter- and intra-species diversity and varying population density of venomous snakes. The impact of snakebite is relatively high in many countries in South- and Southeast Asia, where the overall estimated mortality rate is 1.05 to 5.42 deaths per 100,000 people (4). This includes the Philippines, Thailand, 

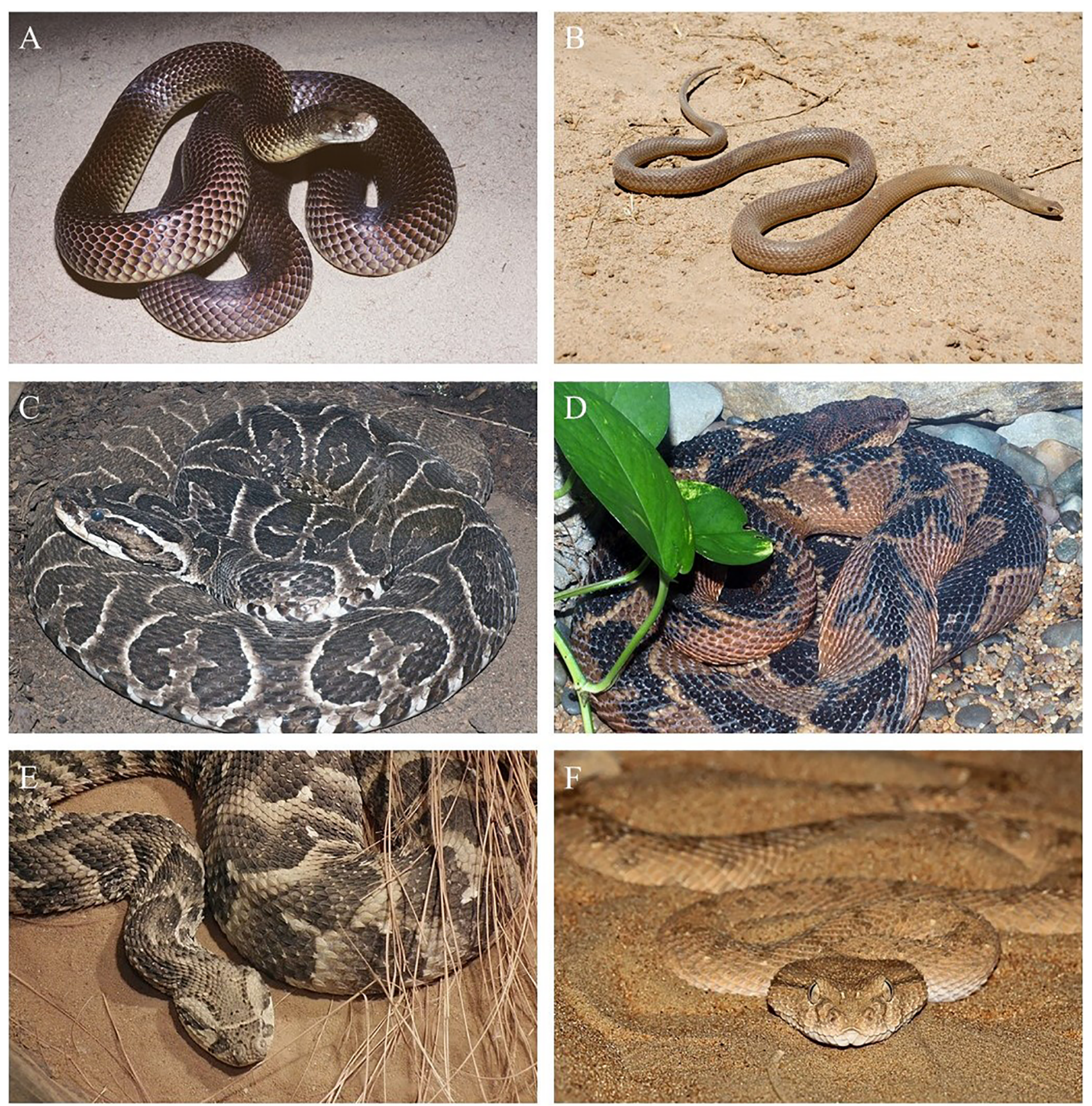

FIGURE 1 | Comparison of venomous snakes with similar names and/or appearance and/or clinical syndromes. Visual comparison of two Australian snakes with similar names and appearances: (A) A king brown snake (Pseudonaja textilis), which belongs to the black snake genus, and (B) an eastern brown snake (Pseudonaja textilis), which belongs to the brown snake genus. Visual comparison of two venomous snake species from Brazil: (C) Bothrops sp. and (D) Lachesis sp. Species from these genera can appear similar to those not trained in snake identification, can cause similar clinical manifestations, and are both locally known as 'surucucu' in certain parts of Brazil. Visual comparison of (E) a puff adder (Bitis arietans) and (F) a horned viper (Cerastes cerastes), the venoms of which can cause similar clinical manifestations. Figures 1A, C, D copyright ${ }^{\circledR}$ Prof. Julian White, Figure 1B copyright ${ }^{\odot}$ of Prof. Sean Bush, 1E, 1F were found on WikiMedia Commons are are copyright ${ }^{\odot}$ of the user $4028 \mathrm{mdk09}$ and the user Broobas, respectively.

Vietnam, Laos, Cambodia, Malaysia, Myanmar, Nepal, Pakistan, Sri Lanka, and India, where envenomings are predominantly incurred from the following snakes: Cobras (Naja spp.), kraits (Bungarus spp.), Russell's vipers (Daboia spp.), saw-scaled vipers
(Echis spp.), Malayan pit viper (Calloselasma rhodostoma), hump-nosed pit vipers (Hypnale spp.), and green pit vipers (Trimeresurus spp.) (114, 127-129). In Japan, Korea, Hong Kong, Taiwan, and Indonesia, most envenomings are caused 


\section{DIAGNOSTIC ALGORITHM FOR AUSTRALIAN SNAKEBITE}

1. Determine likely snakes in the region where patient was bitten (see guide pgs $768,80,82$ ) and use that to consider most likely snake options in algorithms below

\section{LOCAL EFFECTS - Examine the bite site}

\begin{tabular}{|c|c|c|c|}
\hline $\begin{array}{c}\text { Minimal local effects, no significant swelling, } \\
\text { redness, fang marks not prominent }\end{array}$ & $\begin{array}{c}\text { Obvious redness, swelling, bite } \\
\text { marks, } \pm \text { bruising }\end{array}$ \\
\hline $\begin{array}{c}\text { Moderate to } \\
\text { severe local pain }\end{array}$ & $\begin{array}{c}\text { Minimal or no } \\
\text { local pain }\end{array}$ & $\begin{array}{c}\text { Marked swelling } \\
\text { after } 3+\text { hrs }\end{array}$ & $\begin{array}{c}\text { Only mild swell- } \\
\text { ing after 3+ hrs }\end{array}$ \\
\hline $\begin{array}{c}\text { Possibly a death } \\
\text { adder bite }\end{array}$ & $\begin{array}{c}\text { Possibly a } \\
\text { brown snake, or } \\
\text { non-dangerous } \\
\text { elapid } \\
\text { Also consider a } \\
\text { taipan }\end{array}$ & $\begin{array}{c}\text { Possibly mulga } \\
\text { snake, black } \\
\text { snake group } \\
\text { Also consider } \\
\text { yellow faced whip } \\
\text { snake }\end{array}$ & $\begin{array}{c}\text { Possibly a tiger } \\
\text { snake, rough } \\
\text { scaled snake } \\
\text { Also consider a } \\
\text { taipan }\end{array}$ \\
\hline
\end{tabular}

3. SYSTEMIC EFFECTS - Check for coagulopathy, myolysis \& neurotoxicity

Is there a coagulopathy? (bleeding bite, gums, venepunctures or lab evidence)

\section{Yes}
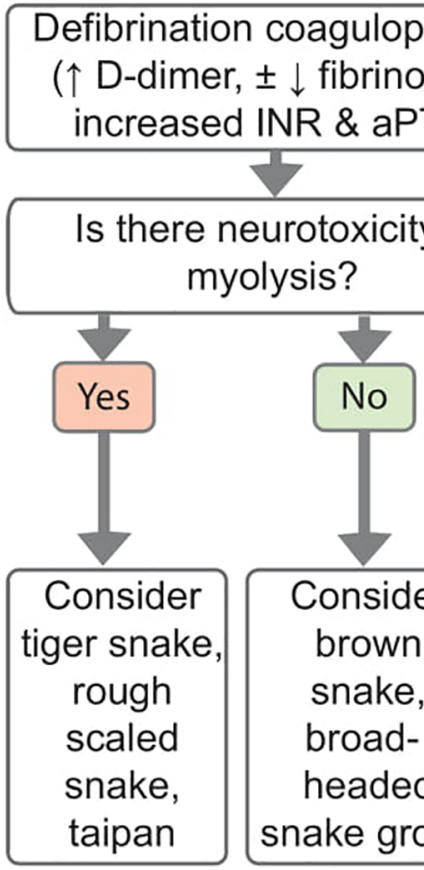

Consider
brown
snake,
broad-
headed
snake group

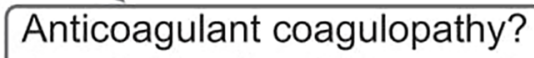

( $\uparrow$ aPTT and/or INR, normal fibrinogen \& D-dimer)

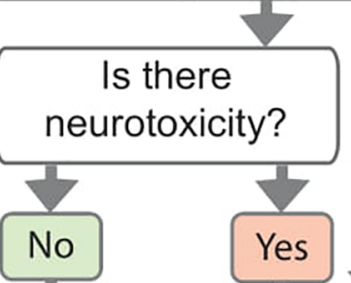

Diagnostic algorithm copyright (C) Prof. Julian White 2018

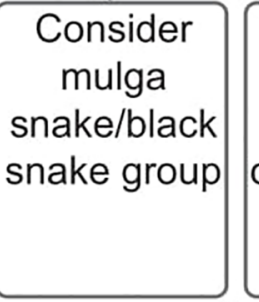

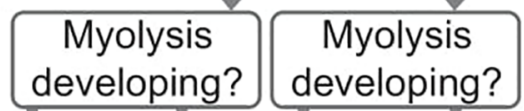

Neurotoxicity developing? (ptosis or worse)
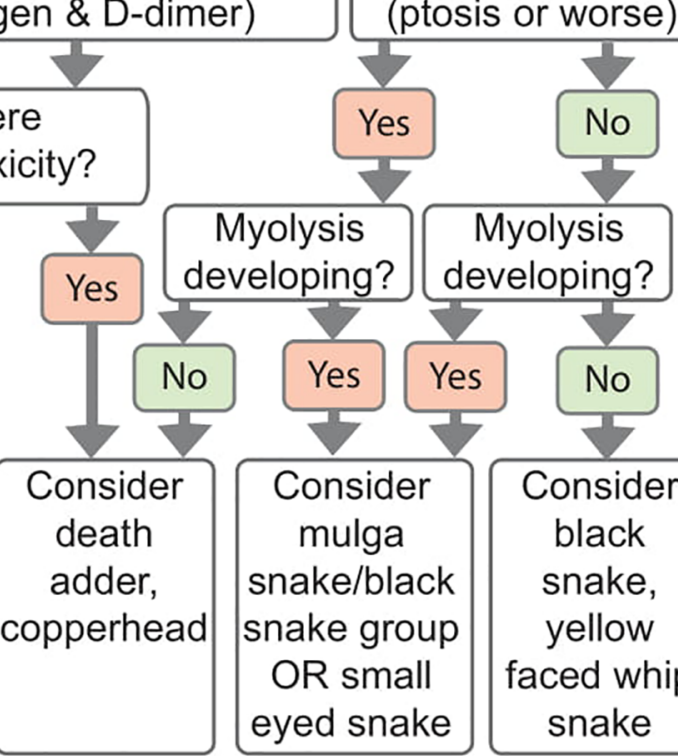

Consider
black
snake,
yellow
faced whip
snake

FIGURE 2 | Diagnostic algorithm for snakebite envenoming in South Australia. Algorithm copyright ${ }^{\odot}$ Prof. Julian White. 
by pit vipers (subfamily: Crotalinae), which might be associated with lower mortality rates (130-134). Data on the epidemiology of snakebite in Central-, West-, and North Asia, including Russia and the Middle East, are limited, but estimates suggest that the rates are low compared to the subtropical and tropical regions of South- and Southeast Asia (4). Similarly, data on the epidemiology in China are limited, with one study suggesting that mortality rates in East Asia, including China, range from 0.033 to 0.347 per 100,000 people (4).

The majority of physicians in South- and Southeast Asia rely on the circumstances of the bite and clinical manifestations to diagnose the victim (135). Syndromic diagnostic tools and algorithms are available for Southeast Asia in general (SEARO guide (136)) and for some countries in particular (e.g. Myanmar $(9,137,138))$. Similar to Australia, a thorough patient history can be helpful in identifying the type of snake involved in the accident. E.g. if a victim has been bitten in a house during the night and has developed paralysis, the culprit is more likely to be a krait (Bungarus spp.), while a bite sustained from a venomous snake in a tree might suggest a green pit viper (Trimeresurus spp.) $(135,139,140)$. Systemic signs of envenoming can also be helpful in clinical practice, as the venom of most species in South- and Southeast Asia are mainly toxic to either neuromuscular or hemostatic systems. Neurotoxicity is often related to bites by cobras, king cobras, and kraits, while hemotoxicity usually indicates envenoming by a true viper (subfamily: Viperinae) or pit viper, although in rare cases it may indicate envenoming by a colubrid, such as a red-necked keelback (Rhabdophis subminiatus) or a tiger keelback (R. tigrinus) (139). It can sometimes be difficult to differentiate between neurotoxic envenoming by cobras and kraits based on clinical signs. However, krait bites are often associated with delayed onset and prolonged total period of paralysis, while cobra bites are often associated with significant local evidence of envenoming $(136,141)$. Behavioral differences of the snakes might further elucidate the matter, as krait bites primarily occur at night, while cobra bites are much more likely to occur during the day $(135,140)$. When documenting the clinical manifestations of envenoming, some clinicians use a standardized questionnaire based on national snakebite management guidelines to support the diagnostic process (142). A systematic syndromic approach combined with a scoring system based on clinical manifestations has been proposed to assist clinicians in identifying the offending snake species (143), but sufficient data on envenoming profiles to create such systems are lacking for many species throughout Southand Southeast Asia $(137,143)$.

India has more snakebites and snakebite-related deaths per year than any other country in the world $(135,144)$. It is home to 52 venomous snake species, out of which the Russell's viper (D. russelii), the common krait (B. Caeruleus), the Indian cobra (N. naja), and the saw-scaled viper (E. Carinatus), known as the "Big Four", are considered the most medically important. Both polyvalent and monovalent antivenoms are available in India, but they do not cover all venomous species. Furthermore, there is a need for a standardized quality control process for manufacturing of snakebite antivenoms to ensure that they are safe and effective (145). National guidelines for management of snakebites in India do exist and some states have developed their own protocols. However, in many cases, these protocols are not followed strictly, leading to misdiagnosis and inappropriate management (146). As an example, hump-nosed pit vipers (H. hypnale) are often misidentified as saw-scaled vipers (E. carinatus), resulting in administration of ineffective antivenom (141). Furthermore, some doctors and hospitals are unwilling to manage snakebite victims, causing potentially critical treatment delays (147). A diagnostic tool for identification of the offending snake species combined with a coordinated approach to ensure that healthcare workers across India have adequate knowledge, skills, and confidence to manage snakebite patients could potentially reduce this problem.

Snakebite envenoming remains an important health issue in many regions of Asia, especially throughout South- and Southeast Asia, where incidence and mortality rates are among the highest in the world. The high species diversity complicates clinical management, although this problem is alleviated somewhat by the widespread use of polyvalent antivenoms. While these polyvalent antivenoms are convenient for physicians, they may arguably be disadvantageous for overall patient outcomes, as they can be a disincentive for quality epidemiologic and clinical envenoming studies. Uncertainty about the offending snake species may result in masking of "new" envenoming syndromes, thereby hampering the inclusion of new species into antivenom immunization protocols. The continuing absence of Hypnale spp. from the immunizing mix for Indian polyvalent antivenoms (148-150) can be mentioned as an example of this.

\section{SNAKEBITE DIAGNOSIS IN THE UNITED STATES AND CANADA}

In the United States (US) and Canada, around 6,500 people suffer from snakebites annually, resulting in 5-6 deaths $(5,151,152)$. The US has about 26 indigenous venomous snake species, where rattlesnakes (Crotalus spp.), moccasins (Agkistrodon spp.), and pygmy rattlesnakes (Sistrurus spp.), all of which belong to the pit viper (Crotalinae) subfamily, are the main genera implicated in snakebites. Coral snakes (Micrurus spp.) are also present in a limited southern distribution but do not account for many bites (153), with an estimated 70-80 annual cases reported to the American Association of Poison Control Centers. In Canada, rattlesnakes are the only medically relevant snake species, and with a very limited distribution, the risk of snakebite is relatively small (154).

Pit vipers are the most prolific group of snakes involved in snakebite accidents in the US and Canada; therefore, when managing a snakebite patient, it is important to keep in mind that less than 10 percent of pit viper bites are dry bites $(155,156)$. Pit viper venom typically contains hemotoxins causing direct or indirect lysis of fibrinogen, thrombocytopenia, and vascular endothelial damage $(157,158)$, thereby emphasizing the 
importance of carefully monitoring the patient's blood coagulation profile through laboratory tests. Furthermore, the presence of Mojave toxin in Mojave rattlesnake (C. scutulatus) and southern pacific rattlesnake ( $C$. helleri) venoms causes potentially severe systemic neurotoxicity, including cranial neuropathy and flaccid paralysis. Severe neurotoxic clinical manifestations, when present, are a relevant diagnostic indicator (159-161). It is recommended to perform laboratory tests of the patient every 6-8 hours and twice prior to discharging the patient in order to follow the progression of the envenoming (110).

Coral snake envenoming generally causes only mild local effects, while the systemic manifestations can include euphoria, lethargy, nausea, vomiting, excessive salivation, ptosis, dyspnea, convulsions, abnormal reflexes, and motor weakness or paralysis leading to respiratory paralysis, which is lethal in absence of clinical intervention (162-165). In case of a coral snake envenoming, serum creatine kinase activity may rise, and myoglobin may be detected in the urine $(164,166)$, but coagulopathy is not a feature (165-168). The observation time in the hospital depends on the severity of the envenoming, the age of patient, and the location of the bite wound, ranging from at least 8 hours to 12-24 hours for mild envenomings, where repeated laboratory evaluations are advised (110). The marked visual appearance and clinical presentation of coral snake envenomings in the US make coral snake envenomings easy to distinguish from pit viper envenomings. The genus-specific antivenom, Pfizer Antivenin, has been available for the treatment of coral snake envenoming but is currently in very short supply, resulting in rationing $(162,169)$, though the recent recommencement of production should alleviate this shortage.

Like several other countries, the US also has a treatment algorithm: The unified treatment algorithm, published in 2011, with the purpose of streamlining the management and diagnosis of snakebites in the US (110). However, since the algorithm was published, a new antivenom has become available, and the algorithm has not yet been updated accordingly. As Canada does not have indigenous snake species that are different from those in the US, it is likely that this algorithm is applicable to assess snakebite cases in Canada as well.

Clinicians in the US will often factor in information provided by the victim or bystanders about the identity of the snake. A study comparing the snake identifications of expert herpetologists with those of snakebite victims, witnesses, and healthcare providers in southern parts of the US found that $40 \%$ of the specimens identified as copperheads (A. contortrix) were actually cottonmouths ( $A$. piscivorous), with juvenile snakes being particularly difficult to identify, leading to confusion (170). While other species were less frequently confused, it might be problematic that (possibly erroneous) snake identifications are used by poison control centers when recommending treatment (170). Although pit viper bites in the US are treated with polyvalent antivenom (CroFab or AnaVip) when required, misidentification of pit vipers might still negatively impact treatment. For example, AnaVip, which is based on equine $\mathrm{F}(\mathrm{ab})_{2}$ antibodies, has proven more efficient in treatment of late onset and recurrent coagulopathy than CroFab, which is based on ovine Fab antibodies (171). This difference in efficacy versus coagulopathies might be related to the different half-lives of Fab and $\mathrm{F}(\mathrm{ab})_{2}$ antivenoms (171). Both CroFab and AnaVip are recommended for treatment of rattlesnake envenoming in North America, but AnaVip has not received FDA-approval for treatment of bites by cottonmouths and copperheads. Conversely, CroFab works well for treatment of copperhead (A. contortrix) bites, by decreasing limb disability subsequent to bites (172) and being associated with fewer patients using opioids to treat pain related to the envenoming (173). It has additionally been demonstrated that early administration of CroFab for copperhead bites results in faster limb recovery than does late administration (174). Thus, in cases of copperhead envenomings, it might be especially beneficial to rapidly identify the culprit species so the optimal polyvalent antivenom can be administered early on.

\section{SNAKEBITE DIAGNOSIS IN LATIN AMERICA}

In Latin America and the Caribbean islands, 80,000-129,000 snakebite envenomings occur each year, leading to an estimated 540-2,300 deaths (4). Throughout the Latin American countries, bites from lanceheads (Bothrops spp.) are the most prevalent. Rattlesnakes (Crotalus spp.), bushmasters (Lachesis spp.), and Coral snakes (Micrurus spp.) are also present, but especially the latter two are far less common causes of snakebites $(175,176)$. In Central America, snakebites are also caused by moccasins (Agkistrodon spp.), jumping pit vipers (Atropoides spp.), palm pit vipers (Bothriechis spp.), montane pit vipers (Cerrophidion spp.), and hog-nosed pit vipers (Porthidium spp.). The venoms of pit vipers indigenous to Central America can be treated with polyvalent antivenom (175). The clinical utilization of polyvalent antivenom makes diagnosis at a species or even genus level less important, as noted earlier for Asia and the US and Canada. However, it is important to determine which family (viper, elapid, or other) the perpetrating snake species belongs to, whether an envenoming has taken place, and the severity of the envenoming (175). For South American countries, both polyvalent and genus-specific antivenoms are available (111, 176-179).

Several Latin American countries have protocols for diagnosis and treatment of snakebite envenoming, describing the use of the syndromic approach and the laboratory investigations mentioned in Table 2 (111, 175, 176, 178-180). Several of these protocols mention coagulation time as a commonly investigated parameter for early detection of a pit viper envenoming $(111,175,176,178-180)$. Often in pit viper envenomings, the 20WBCT is positive (no clot at 20 minutes), while for elapids it remains negative (normal clot at 20 mins) (165-168). In Mexico, where rattlesnakes are the predominant genus, the Lee-White clotting time (LWCT) is utilized to determine the presence of coagulation disorders, which can in 
turn give an indication of the urgency of commencing treatment (180). LWCT is fundamentally similar to the 20WBCT described earlier, with the only difference being that the LWCT is observed once per minute after an initial incubation time of five minutes (181). The effectiveness of LWCT was assessed in Brazil for its sensitivity toward detecting coagulopathy in lancehead envenomings and was considered a valuable tool in evaluating the need for antivenom therapy (181).

Pit viper envenomings may cause both local and systemic effects, but there are two distinct patterns. Most Central and South American pit vipers cause moderate to severe local effects and coagulopathy, often with hemorrhagic features. The exception is rattlesnakes, which are more likely to cause major systemic effects including neurotoxicity, rhabdomyolysis, and coagulopathy, while only causing mild local effects. Local effects following pit viper bite, with the exception of rattlesnakes, may include edema, severe local pain, swelling, local hemorrhage, inflammatory erythema, lymphangitis, bleeding from the bite wound, blistering, ecchymosis, tissue necrosis, and secondary infections (7, 111, 175, 176, 178-180, 182-185). Systemic effects may include early syncope, confusion, transient loss of vision or darkening of vision, hypotension, shock, renal damage, cardiac tachyarrhythmia or bradyarrhythmia, coagulopathy, and systemic hemorrhage $(7,111,175,176,178-180,182,183$, 185). With the knowledge of which snakes induce which clinical manifestations, the syndromic approach works well and is widely used. However, the approach requires thorough knowledge of the different venomous snakes $(7,186)$ and relies on the presence of polyvalent antivenoms targeting the venoms of one or multiple genera.

The similarity between the local effects of lancehead species and bushmaster species makes differentiating the two a challenging task, which can be further complicated by the fact that, in some regions, both genera are known locally as "surucucu" (see Figures 1C, D). However, the vagomimetic effects, sometimes induced by bushmaster venom on the gastrointestinal system, may cause diarrhoea, thus indicating the most likely genus of the culprit snake. Although this can be a strong indicator, the lack of such effects does not exclude the presence of a lachetic envenoming $(151,176)$, nor do their existence confirm it.

Unlike bites from lanceheads and bushmasters, many rattlesnake bites are more easily recognized by the neurotoxic effects that they can inflict. South American rattlesnakes (C. durissus) generally do not cause severe local manifestations but instead induce neurotoxicity resulting in neuromuscular paralysis $(183,184,187)$, caused by neurotoxic crotamines and crotoxins present in the venoms. Envenomings by South American rattlesnakes often lead to mild to severe neurotoxic manifestations in the patient, which are clinical hallmarks that may guide the physician toward a correct diagnostic assessment $(111,159-161,176,178,180)$. However, it has been reported that envenomings by juvenile South American rattlesnakes can result in coagulopathy as the main systemic manifestation, instead of neurotoxicity, which may lead to misdiagnosis and administration of wrong antivenom (188).
Coral snake envenomings are associated with very different clinical manifestations, such as local paresthesias, vomiting, muscle paralysis including paralysis of respiratory muscles, ptosis, ophthalmoplegia, diplopia, and late manifestations including secondary renal damage and respiratory failure (111, $168,175,176,178-180,183,184)$. Although clinical manifestations may overlap with those of some rattlesnakes, the recognizable color schemes of coral snakes make a strong case for coral snake envenoming. Coral snakes found in most of the Pan-American countries are visually very distinct from pit vipers. However, nonvenomous snake species mimicking the venomous coral snakes exist (e.g. milk snakes: Lampropeltis triangulum). These are difficult to distinguish by a nonprofessional, but guidelines based on the color scheme of the snakes can be found that aid in the differentiation $(162,175,189)$.

Snake biodiversity varies significantly throughout Latin America, from Argentina inhabited by three medically important snake genera (Bothrops, Crotalus, and Micrurus) to the plethora of medically important species found in Mexico and the Central American countries (190). This shift in indigenous snake species greatly impacts the diagnostic approach, where the severe local effects of lancehead envenomings become a specific indicator in Argentina (111), but is easily confused for a lachetic envenoming in Brazil (176). Polyvalent antivenoms alleviate the dependence on successful determination of the species of the culprit snake by simply requiring successful assessment of the snake family involved. However, as discussed previously, there may be disadvantages to being restricted to polyvalent antivenoms, and different polyvalent antivenoms may perform differently in a given clinical case.

\section{SNAKEBITE DIAGNOSIS IN AFRICA}

The extent of the snakebite problem in Africa is difficult to assess due to the scarcity of epidemiological data (182). However, of all the African regions affected, snakebite is most commonly observed in sub-Saharan Africa, where an estimated 90,000420,000 envenomings occur annually, resulting in 3,000-32,000 deaths (5). In comparison, an estimated number of 3,000-80,000 bites occur in North Africa and the Middle East combined, leading to 4,000-8,000 deaths annually (5). To the best of our knowledge, a combined mortality rate for all of Africa has not been recorded, but it has been estimated that some of the populations most vulnerable to snakebite worldwide are found in Africa (191). The snakes that are responsible for the majority of bites and are associated with serious or life-threatening envenomings are saw-scaled vipers (Echis spp.), large African adders or vipers (Bitis spp.), spitting or cytotoxic cobras (Naja spp.), neurotoxic cobras (Naja spp.), and mambas (Dendroaspis spp.) (192). In addition to the potency of the snake venoms themselves, factors potentially contributing to the high mortality rate may include scarcity of antivenoms (partially due to the high cost of antivenoms relative to personal income levels), low quality, inappropriate, or counterfeit antivenoms, suboptimal health services, difficulties with quick access to health centers, 
and insufficient training in clinical snakebite management, including a lack of diagnostic training and/or tests (2, 193-196).

In many African cases, appropriate clinical management of snakebite patients requires identification of the distinctive clinical syndrome based on epidemiological, clinical, and laboratory data (e.g. 20WBCT), and consequently the syndromic approach is often recommended (15). Researchers and clinicians have sought to objectively quantify the severity of snakebite envenoming to minimize confusion due to the ambiguity of the definitions offered by current guidelines (197). In Southern Africa, five main clinical syndromes of snakebite envenoming are recognized and often these guide diagnosis: Local pain and progressive swelling (cytotoxicity), progressive paralysis (neurotoxicity), incoagulable blood (hemotoxicity), moderate to marked local swelling (associated with otherwise neurotoxic bites), and mild to moderate swelling, with negligible or absent systemic effects (neurotoxicity and cytotoxicity) (15). However, with the syndromic approach, it is possible to misidentify snake species due to the similarity between symptoms that develop following envenoming from different types of snakes. For instance, mixed hemorrhagic and cytotoxic symptoms develop following envenoming caused by saw-scaled vipers, puff adders (Bitis arietans), and horned desert vipers (Cerastes cerastes) (see Figures 1E, F) (192).

Several polyvalent and a few monovalent antivenoms have been marketed for the treatment of envenomings caused by African snake species, but the antivenoms are not necessarily equally appropriate for the treatment of bites from a given genus or species, in spite of being marketed as such (198-201). The antivenoms are also not evenly distributed throughout the continent, and some areas have been plagued by antivenom shortages $(2,193,196,202)$. It might therefore be expected that the disparity in the availability and types of antivenoms in Africa is reflected by a variability in the demands for diagnosis. However, to be diagnosed or treated, the patient must make their way to either a health center or a properly trained clinician, which may often be difficult or result in long delays. A study published in 2015 estimated that about $29 \%$ of the population in Africa are geographically marginalized from emergency medical care and live more than two hours from the nearest public hospital (203). The same study found that only 16 of 48 countries have more than $80 \%$ of their population living within two hours' travel time of emergency hospital care (203). Thus, it is no surprise that many snakebite victims in rural communities resort to seeking out traditional healers, rather than trained physicians (195). This trend is also observed outside of Africa, when looking at other rural parts of the world that are heavily burdened by snakebite (204-209). This delay in receiving proper medical care will, in most cases, worsen the symptoms and thus increase the likelihood of a poorer clinical outcome $(206,210)$.

For diagnosis, management, and treatment of snakebite victims in Africa to improve, it will be essential to address the knowledge gap between the health institutions, rural communities, and their local traditional healers (206). One strategy to approach this is via outreach and education programs promoting snakebite prevention and first aid (211).
Such programs could even include traditional healers in an attempt to utilize their status as authority figures (211), rather than attempting to fight strongly-held community cultural beliefs. Also, increased availability of mobile phones with inbuilt cameras could facilitate the involvement of (distantly located) expert herpetologists in snake species identification without the need to capture or kill the snake $(206,212)$.

\section{SNAKEBITE DIAGNOSIS IN EUROPE}

Snakebite incidents are a relatively rare occurrence in Europe with an incidence rate of 1.06 bites per 100,000 people and about 4 deaths annually (213). Contrary to what some believe, snakebites from species indigenous to Europe can cause severe envenoming and require immediate medical attention. All significantly venomous snakes in Europe belong to the Viperinae subfamily, with the common European adder (Vipera berus), European asps (V. aspis), and common sand adder ( $V$. ammodytes) being responsible for the largest proportion of severe envenomings $(213,214)$.

Many areas of Europe are inhabited by only one species of venomous snake, especially in Northern and Central Europe $(213,214)$. If diagnosis is necessary in areas with more than one species, it is usually based on witness statements, a picture of the culprit snake, or the snake itself brought by the victim (215-217). In severe cases, the presence of neurotoxicity can be an indication that the envenoming was caused by either a common sand adder or a European asp, as these two species are the most common causes of neurotoxicity due to envenoming by indigenous European snakes. Additionally, because these species have disjunct distributions, neurotoxicity can help pinpoint exactly which species caused the bite (213, 218). However, the absence of neurotoxicity does not exclude European asp bites, as most subpopulations do not possess neurotoxic venom (219). Neurotoxic clinical features have also occasionally been reported after envenoming by the common European adder, but this has been limited to a few geographical areas in Eastern Europe and has mostly been caused by the subspecies known as the Bosnian viper (V. berus bosniensis) (216, $217,220)$. For this reason, in most of Europe, elaborate laboratory tests for diagnosis of the culprit snake species is a low priority. However, laboratory tests are used to assess the severity of envenoming, and thereby the need for antivenom $(214,221)$. Clinical manifestations monitored include hypotension, neurologic or gastrointestinal symptoms, edema, and leukocytosis. A full overview of clinical manifestations is given elsewhere (222).

Snakes inject a variable amount of venom and dry bites can occur (223-226). Victims are normally admitted for observation for 24 hours to monitor possible symptom progression (225, 227). Despite the impracticality of using clinical signs for diagnosing the species involved in most European snakebites, the severity of the symptoms and signs can be used to determine the need of antivenom administration in moderate to severe envenomings. A grading system for assessing the severity of an 
envenoming has been proposed based on data on the appearance of clinical manifestations from common European adder and European asp cases and has been used as a guideline in research and in certain clinical settings (53, 221, 225, 228).

Despite the close phylogenetic relationship between Vipera spp., inter- and intraspecific venom variability might occur, both with regard to the toxins present and their individual abundances, which, in turn, may affect antivenom efficacy (213, 229-231). However, available monospecific antivenoms may still show cross-reactivity between venoms, and studies have shown that antivenom raised against venom from one species can, in some cases, have clinical efficacy against venoms from other vipers indigenous to Europe $(214,215,232)$.

Bites by exotic snakes are not as prevalent as those by indigenous species. However, they are still the cause of a few severe bites around Europe, mostly affecting amateur snake keepers (233-235). In these cases, rapid identification of the responsible species is important as it can help predict clinical manifestations and aid symptomatic treatment. As the snake is not endemic to the country, clinicians will usually rely on statements from witnesses for identification, and required antivenom should be sourced as soon as possible as it might not be stocked in the given country (236) (exotic antivenom banks exist in a few countries, e.g. the Netherlands and Germany).

\section{POTENTIAL BENEFITS OF NOVEL SNAKEBITE DIAGNOSTICS}

Studies find that early treatment of Australian and North American snakebite victims is linked to faster recovery and shorter time to hospital discharge $(126,174)$. In a similar vein of inquiry, it was established that delays in treatment increase the risk of acute kidney injury in snakebite victims in Myanmar and the risk of acute renal failure and the overall severity of envenoming in snakebite victims in Brazil (237-239). One of the studies also found that patients who developed acute renal failure required more antivenom and were hospitalized for a longer period of time than those who did not (238). These studies point to the unsurprising conclusion that delays in treatment often negatively impact patient outcome, which in turn can result in prolonged hospitalization time and increased resource consumption at the treatment facility. It thus seems plausible that improved diagnostics might enable rapid diagnosis and thereby facilitate early and correct treatment, as well as improved patient outcomes. This is backed by a recent study of 742 snakebite patients in Sri Lanka, which argues that delays in antivenom administration reflect an absence of diagnostics for early detection of envenoming, and that such diagnostics are required for improved, early treatment with antivenom (240). Novel diagnostics will likely have the greatest impact in areas where transportation to the treatment facility and antivenom availability are not limiting factors, areas with many different indigenous snake species that are visually difficult to discern, areas where monovalent antivenoms are available, and areas with medical or paramedical personnel with limited training in clinical management of snakebite envenoming.

In addition to their utility in supporting clinicians in diagnosing snakebite patients and choosing the correct antivenom on a case-by-case basis, novel snakebite diagnostics could also be of interest on a grander scale. They could enable epidemiologists to map patterns of snakebite incidence. In turn, knowing which snake species are responsible for the majority of bites in an area can help authorities manage their resources, when deciding which antivenoms to procure in which quantities, and where to deploy them within a healthcare system (241). Improved diagnostics might also inform the design of novel antivenoms, and they could become indispensable tools for clinical trials of future generations of antivenoms, and later (if adopted as companion diagnostics) in clinical snakebite management. Based on the potential use cases and benefits listed above, it is perhaps hardly surprising that researchers and physicians have indicated the need for improved diagnosis of snakebite victims for decades (7, 83, 240, 242-248).

\section{SNAKEBITE DIAGNOSTICS REPORTED IN THE LITERATURE}

Several diagnostic assays have been developed to meet the demand for improved diagnosis of snakebite victims. The diagnostics rely on techniques varying from immunoassays (typically ELISAs), over enzymatic activity assays, to forensic genetic methods (see Table 1). These studies demonstrate that snakebite envenoming can be diagnosed using various technologies, and they showcase the development of snakebite diagnostics throughout the past six decades. As evident from Table 1, there has been a gradual shift in the preferred methodologies from radioimmunoassays and agglutination tests over the ever-popular ELISA format, toward an increased focus on LFAs and more diverse non-immunological methods. As a reflection of this technological progression, the experimental diagnostics reported in literature have become faster over time, although interestingly, their limits of detection do not seem to have improved significantly. One hypothesis explaining this could be that, while faster immunoassays have been developed, the antibodies at the core of these assays are essentially unchanged, with most still being derived from horses, rodents, and lagomorphs (see Table $\mathbf{1}$ ).

Many of the earliest reported diagnostic tests for snakebites were developed for first-world countries, with Australia being prominently featured (see Table 1). However, this trend has changed, and snakebite diagnostics have now been developed for countries all over the world. As an example, in Brazil, an ELISAbased diagnostic tool has been utilized experimentally to aid differential diagnosis on a genus level (176). Similar assays have been developed that make it possible to evaluate the effectiveness of the antivenom administered to neutralize the venom (176). More recent examples of innovation within snakebite diagnostics in Brazil include an impedimetric immunosensor based on electrochemical impedance spectroscopy (86) and the use of 
infrared thermography (94). Meanwhile in Asia, Hung et al. developed a sandwich-type enzyme-linked immunosorbent assay (ELISA) capable of detecting Taiwan cobra ( $N$. atra) venom in biological samples with a detection limit of $1 \mathrm{ng} / \mathrm{mL}$ (72). The same group later developed an immunochromatographic strip to detect Taiwan cobra venom in patient serum in only 20 minutes (82), while a different group similarly developed an ELISA and an immunochromatographic strip for diagnosis of snake species in Taiwan (85). A number of other molecular diagnostic PCRbased tests for stratifying venom from Asian snake species have also been reported. However, these tests typically take at least 3-4 hours to complete and have lower specificity compared to immunoassays (90-92, 249). Generally, issues with crossreactivity of the tests toward several species remains a problem for rapid diagnosis of snakebite envenoming, and many reported rapid diagnostic methods are not reliable enough for clinical use and can only be used for research purposes (30, 40, 71, 73, $76,77)$.

Although the studies referenced above clearly demonstrate that snakebite diagnostics can be developed for the stratification of many snake species and using many methods, to the best of our knowledge, the SVDK is the only snakebite diagnostic to have been adopted in the clinical setting. The success of the SVDK in Australia may reflect the preference there for using monovalent antivenoms, unlike many other countries, which rely on polyvalent antivenoms. This reliance could create a barrier for adoption of venom detection tests. Generally speaking, the reason for the low adoption rate for novel diagnostic assays is not entirely clear, but a variety of explanations of both technical, financial, and implementational nature are likely to be part of the underlying cause (250). The antivenom market is notoriously financially unstable in many regions (196), and if this is any indication, it leaves little financial incentive for marketing snakebite diagnostics. To exacerbate the problem, snakebite diagnostics are perhaps above all else needed by clinicians in remote healthcare facilities with no training in clinical snakebite management. A lack of education in snakebite management among the users of future diagnostics might complicate the implementation of the diagnostics. Even if these and other financial and implementational challenges can be surmounted, a number of technical pitfalls still exist that one needs to be aware of. Below follows a discussion of some of these pitfalls and design considerations that developers of snakebite diagnostics should take into account to avoid them.

\section{DESIGN CONSIDERATIONS FOR SNAKEBITE DIAGNOSTICS}

When developing a diagnostic for a Neglected Tropical Disease, one of the most important factors to consider is affordability. The association between snakebite envenoming and poverty greatly affects the availability of treatment $(2,7,11,12,251,252)$, and this link between affordability and availability is likely to also exist for diagnostics. Affordability may place restrictions on the types of equipment required to use the diagnostic, especially at small, remote treatment facilities, where access to electricity can be unreliable, and for point-of-care testing. Point-of-care testing additionally requires greater user-friendliness, as the person carrying out the test may have received only limited or no training in its use. For these reasons, a PCR with a low limit of detection and a requirement for specialized laboratory equipment and knowhow, such as that developed by Supikamolseni et al. (91), and a user-friendly lateral flow assay with a higher limit of detection, such as that developed by Liu et al. (85), may be differentially suited for use at centralized treatment facilities and point-of-care settings, respectively. However, with the implementation of different types of PCR [see e.g (253-255)], it will likely be possible to make fast, userfriendly, PCR-based diagnostics for point-of-care testing in the future.

The sample matrix and sampling method should also be considered and as far as possible be adapted to the intended use case. In a healthcare facility, it may be convenient to use blood samples for diagnostics, as it is a standard procedure to take blood samples from snakebite patients for use in the existing laboratory diagnosis $(192,256)$. However, in point-of-care use cases, wound swabs and exudates may be more readily available. While the sampling method affects user-friendliness, the sample matrix may affect the technical specifications of the diagnostic, as different sample types are likely to contain different concentrations of the analyte at different time points, as well as different concentrations of interfering substances (i.e. substances that alter the detected concentration of the analyte). For example, blood samples have notoriously complex compositions compared to e.g. urine samples, and this increases the risk of blood samples containing interferants. Conversely, the collection of blood samples at healthcare facilities is a highly standardized procedure, unlike the collection of wound swab samples, which may additionally be affected by subjection of the bite wound to inappropriate first aid methods or other forms of tampering. Being collected from the surface of the body, wound swab samples may not be representative of the amount of venom actually delivered into the body of a victim, although they may still provide valuable information about the type of snake involved. As demonstrated in Table 1, diagnostics have been developed and tested on various different sample matrices, including blood (and as derivatives hereof: Plasma and serum), urine, tissue samples, wound exudate, and wound swabs. Preferences for the sample matrix vary, with some researchers placing more emphasis on standardization and how well the venom content in the sample type reflects the venom content at the active sites in the body, while others emphasize userfriendliness and a low risk of interference from other sample components. Perhaps to account for the advantages and disadvantages of the various sample types, some assays, e.g. the SVDK from Australia, function with multiple different sample matrices (257).

An additional factor to consider is the time required to use the diagnostic. Because snakebite envenoming is acute in nature, with some toxins exerting their effects within minutes, it would likely be beneficial for a diagnostic device intended for clinical 
use to function on a timescale of minutes rather than hours. Conversely, for forensic and purely epidemiological studies, rapid assay time may not be a requirement. Therefore, timeconsuming diagnostics, such as ELISAs with overnight incubations, may be as well-suited for retrospective diagnosis as more rapid assays. Furthermore, it is advantageous for the diagnostic tool to be stable over a wide range of temperatures and environmental conditions, as the provision of cold-storage may be problematic in some areas of the world $(16,241)$.

Important technical parameters, which are not specific to snakebite, also need to be considered, including specificity, sensitivity, and positive predictive value. Low specificity (i.e. the number of true negatives divided by the total number of individuals not suffering from a condition) leads to false positives, as demonstrated in a study by Ho et al. (40), where the researchers set up an ELISA to study snakebites in rural Thailand. Here, non-specific reactions of ELISA reagents led to a false positive rate of up to $75 \%$ (40). A study by Isbister et al. demonstrated how low sensitivity (i.e. the number of true positives divided by the total number of individuals with the condition) of the 20WBCT for Russell's viper envenoming led to a high rate of false negatives, which in some cases resulted in delayed antivenom administration (258). If the sensitivity, specificity, and disease prevalence are known, they can be used to calculate the positive predictive value, using the formula:

$$
\text { Positive predictive value }=\frac{\text { sensitivity } \cdot \text { prevalence }}{\text { sensitivity } \cdot \text { prevalence }+(1-\text { specificity }) \cdot(1-\text { prevalence })}
$$

The positive predictive value is an indication of how likely patients with positive test results are to truly suffer from a condition (e.g. snakebite envenoming sustained by a cobra). Unfortunately, although $\mathrm{Ho}$ et al. argued the importance of reporting these measurements of assay performance already in 1986 (40), very few studies involving snakebite diagnostics contain these values, and some diagnostics are not even tested on patient samples (see Table 1). The absence of positive predictive values for snakebite diagnostics in the literature may be a reflection of the lack of available data on disease prevalence. As more epidemiological data hopefully becomes available, it may become easier to evaluate the potential of novel diagnostics by using the positive predictive value as a performance measurement.

Additional technical parameters of importance include limit of detection (LoD), quantitativity, and limit of quantitation (LoQ). In the literature, snakebite diagnostics have been reported with limits of detection (i.e. the lowest concentration of a substance that can be distinguished from the absence of the substance) ranging from $0.1 \mathrm{pg} / \mathrm{mL}$ to $0.3 \mathrm{mg} / \mathrm{mL}$ (see Table 1). The limit of detection required depends on the pharmaco-/ toxicokinetics of the analyte. For example, if the analyte has a short half-life and a high volume of distribution, the limit of detection in a blood sample will need to be much lower than for an analyte with a long half-life and low volume of distribution. The influence of analyte kinetics is also relevant when discussing quantitative diagnostics. Quantitative diagnostics are interesting, because they can provide information not only about the presence of an analyte but also about its abundance. For quantitative assays, in addition to establishing the limit of quantitation (the lowest amount of analyte that can be quantitatively measured with a certain precision and accuracy), it may also be important to establish threshold values. For example, if the analyte measured is a biomarker of kidney injury, which is also found in low amounts in healthy individuals, it is important to determine a threshold value to distinguish patients with normal amounts of biomarker from patients with abnormal amounts. If the analyte is a snake venom toxin, it might be relevant to determine several thresholds corresponding to commonly used categorizations of "mild", "moderate", and "severe" envenomings, which correspond to different treatment strategies. Quantitative diagnostics could potentially also be used to evaluate the effectiveness with which antivenoms sequester toxins, by monitoring unbound toxins in blood samples from patients. This could make quantitative diagnostics useful tools for antivenom performance evaluation and monitoring of patients' disease progression/envenoming grade alike. A low level of free toxins might mislead nontoxinologist clinicians into believing the patient can be discharged, but due to a depot effect and a mismatch between the toxicokinetics of the venom and the pharmacokinetics of the antivenom, symptoms can recur (259). Potentially, if patients are kept under observation, quantitative diagnostics will enable clinicians to detect an increase in free toxin levels, before symptoms recur, and prepare accordingly. However, the Achilles' heel of diagnostics relying on toxin detection may be the underlying assumption that the toxin concentration is measurable in a readily available sample, and that this concentration is always reflective of the toxin concentration at the site where the toxin exerts its effects. While some studies have found correlations between venom antigen concentration in patient samples and certain clinical manifestations of envenoming, others have found the opposite $(52,53,69,260$ 262). This dichotomy underlines the complexity of the relationship between toxin concentration and distribution over time (263). The matter is complicated further for both toxin and non-toxin analytes, if the influence of preexisting morbidities on the analyte's kinetics is factored in. For instance, diseases such as chronic kidney disease may alter the clearance or even the baseline concentration of an analyte (if the analyte is a naturally occurring biomarker, see (264) for examples). The disparity between measured analyte concentration and signs of envenoming might be alleviated by using samples of the affected tissues instead of more distant tissues, e.g. by using a muscle biopsy instead of using a wound swab, if one is trying to assess myotoxicity. However, for clinical (as opposed to forensic) samples, this strategy could be highly problematic, as the risks involved for the envenomed patient may outweigh the potential benefits. If, in spite of these challenges, any meaningful thresholds can be established for quantitative diagnostics, it will be important that assay precision and accuracy are high in the surrounding range. It should also be determined in which range there is a linear correlation between actual and measured analyte concentration, and whether the assay is affected by the hook effect. 
As evidenced by Table 1, many snakebite diagnostics have been developed using immunological methods, often using equine, leporine, or murine IgGs. For diagnostic immunoassays, it may be worth considering the format and origin of the antibodies used. While format and origin are key decisions that greatly affect antivenom utility (177), these antibody properties may be somewhat less influential in diagnostics, because the diagnostic antibodies are not injected, thus rendering their pharmacokinetics and pharmacodynamics irrelevant. However, it is still possible that endogenous factors in a patient sample (e.g. anti-idiotypic antibodies, other heterophilic antibodies, or factors in a blood sample) can react with heterologous antibodies on a diagnostic test, thereby causing a high background signal, which needs to be accounted for (40). In addition to establishing standard curves and subtracting such background signals, less laborious options are available. For example, it might be possible to use a different sample type that does not contain the problematic factors or to filter the problematic factors out of the originally selected sample type, especially if their sizes are very different from that of the analyte [see e.g $(265,266)]$. Alternatively, an excess of unspecific antibody could be added to outcompete the diagnostic antibodies for unspecific binding to the interfering factors. The antibody format should also be considered, as different antibody formats have different avidities and different options for chemical modifications, such as linkage to dyes and tags or attachment to surfaces or larger particles $(267,268)$.

It is also important to consider which information is of most use for treatment. Several parameters exist that, if measured, could provide useful information to the treating physician. For example, measurement of biomarkers for the development of clinical manifestations is already used to help physicians identify and predict pathologies such as coagulopathies, rhabdomyolysis, and acute kidney injury (7, 109, 256). Detection of snake venom toxins and/or identification of snake species is also of interest, as knowing the snake species or type of venom injected into the victim can aid in deciding which antivenom (if any) is appropriate, as well as it might help predict later clinical manifestations. It may be relevant to distinguish which snakes are of greatest interest to discern from an epidemiological and a clinical viewpoint, respectively. For example, snake stratification at a species level may be very valuable in epidemiological studies, as it can uncover neglected species, which should be included in future antivenoms. Conversely, stratification at the species level may be entirely irrelevant from a clinical perspective, if no species-specific antivenoms are available. As such, the taxonomic level at which snakes should be differentiated depends on the intended usage of the diagnostic, and for diagnostics intended to support clinicians in deciding on treatment, it will depend on the treatments available in that area. Whichever analyte is chosen, it will inform subsequent interference studies (i.e. studies that determine which, if any, substances from patient samples interfere with the measured analyte concentration). E.g., if the diagnostic measures the concentration of a cobra cytotoxin in order to diagnose a patient with cytotoxic cobra envenoming, it should be investigated whether the diagnostic also reacts with cytotoxins from the venoms of other snakes found in the same area. Additionally, in this example it should be tested whether antibiotics (which are sometimes administered to fight infections at the bitesite), prophylactically administered antivenom, or other factors found in the sample matrix (e.g. anti-idiotypic antibodies as mentioned above or medications used to treat preexisting morbidities) can interfere with analyte measurement, e.g. by potentiating the enzymatic activities of snake venom toxins (269). Several of the studies listed in Table 1 describe investigations of the potential for cross-reactivity with other snake venoms, with some studies having screened multiple venoms, and others only a few, but none of the studies report a broader, systematic screening for interferents.

Ultimately, the design of a novel diagnostic will be fraught with compromises, as developers will have to weigh the pros and cons of diagnostic technologies for different applications. Comparatively slow and sensitive ELISAs may be ideal for coroners and researchers attempting to retrospectively identify the type of venom that caused a patient's death, while rapid and user-friendly, albeit potentially less sensitive, LFAs may be preferable to first-responders trying to decide on appropriate first aid (or maybe, in the future, to decide on whether to use first-line-of-defense drugs, such as varespladib or batimastat). The most desirable properties of a diagnostic will thus always be determined by its intended usage, and it is unlikely that there will be a one-size-fits-all solution to developing snake venom diagnostics. Rather, multiple technologies are likely to find use in various applications.

TABLE 3 | Overview of clinically commonly used diagnostic methods for snakebite envenoming in different parts of the world.

\begin{tabular}{|c|c|c|c|c|c|c|}
\hline & Syndromic approach & Visual identification of the snake, if available & Patient history & 20WBCT & Lab. tests & Immuno-assays \\
\hline Australia & $\checkmark$ & $\checkmark$ & $\checkmark$ & $(\sqrt{ })$ & $\sqrt{ }$ & $\checkmark$ \\
\hline Africa & $\checkmark$ & $\checkmark$ & $\checkmark$ & $\checkmark$ & $(\sqrt{ })$ & \\
\hline Asia & $\checkmark$ & $\checkmark$ & $\checkmark$ & $\checkmark$ & $(\sqrt{ })$ & \\
\hline Europe & $\checkmark$ & $\checkmark$ & $\checkmark$ & & $\checkmark$ & \\
\hline North America & $\checkmark$ & $\checkmark$ & $\checkmark$ & $(\sqrt{ })$ & $\checkmark$ & \\
\hline Latin America & $\checkmark$ & $\checkmark$ & $\checkmark$ & $\checkmark$ & $(\sqrt{ })$ & \\
\hline
\end{tabular}

Diagnostic methods can vary between and within countries in these regions, and tick marks in parentheses indicate that the method is infrequently used or only used in relatively few areas. 
Novel diagnostic tools for snakebite envenoming and snake identification do not have to come in the form of bioassays. Recently, an alternative was proposed with the suggestion that apps capable of recognizing photos of biting snakes and/or matching syndromes to snakes could empower healthcare providers and facilitate better treatment (212). Additionally, improved diagnosis of snakebite victims will likely depend on other initiatives in addition to novel diagnostics. For instance, studies from multiple different countries indicate that misidentification of snakes occurs, and in some cases prompts inadequate treatment $(112,115,170,270-273)$. Several authorities have therefore indicated the need for improved education and training of healthcare workers (7, 9, 244, 252, 274-277), a sentiment that is echoed in the World Health Organization's 2019 strategy for snakebite envenoming (211).

\section{CONCLUSION}

Snakebite envenoming has long been neglected, and the lack of care is - in the words of Williams et al. - a cruel anachronism (278). This neglect affects education, treatment, and diagnosis, none of which have received the attention or resources they deserve. However, with the reinstatement of snakebite envenoming on the World Health Organization's list of topprioritized Neglected Tropical Diseases in 2017, snakebite is garnering more attention, funding, and resources. This constitutes an excellent opportunity for scientists, physicians, and other stakeholders (many of whom have been working tirelessly for decades to alleviate the burden of snakebite envenoming) to critically revisit both current practices and new efforts within clinical snakebite management. In this

\section{REFERENCES}

1. Mohapatra B, Warrell DA, Suraweera W, Bhatia P, Dhingra N, Jotkar RM, et al. Snakebite mortality in India: A nationally representative mortality survey. PloS Negl Trop Dis (2011) 5:1-8. doi: 10.1371/journal.pntd.0001018

2. Brown NI. Consequences of neglect: Analysis of the sub-saharan african snake antivenom market and the global context. PloS Negl Trop Dis (2012) 6: e1670. doi: 10.1371/journal.pntd.0001670

3. Fox S, Rathuwithana AC, Kasturiratne A, Lalloo DG, de Silva HJ. Underestimation of snakebite mortality by hospital statistics in the Monaragala District of Sri Lanka. Trans R Soc Trop Med Hyg (2006) 100:693-5. doi: 10.1016/j.trstmh.2005.09.003

4. Kasturiratne A, Wickremasinghe AR, De Silva N, Gunawardena NK, Pathmeswaran A, Premaratna R, et al. The global burden of snakebite: A literature analysis and modelling based on regional estimates of envenoming and deaths. PloS Med (2008) 5:1591-604. doi: 10.1371/journal.pmed.0050218

5. Chippaux J-P. Snake-bites: appraisal of the global situation. WHO Bull OMS (1998) 76:515-24.

6. Swaroop S, Grab B. Snakebite mortality in the world. Bull World Health Organ (1954) 10:35-76.

7. Gutiérrez JM, Calvete JJ, Habib AG, Harrison RA, Williams DJ, Warrell DA. Snakebite envenoming. Nat Rev Dis Prim (2017) 3:17063. doi: 10.1038/ nrdp. 2017.63

8. Habib AG, Kuznik A, Hamza M, Abdullahi MI, Chedi BA, Chippaux J-P, et al. Snakebite is Under Appreciated: Appraisal of Burden from West Africa. PloS Negl Trop Dis (2015) 9:4-11. doi: 10.1371/journal.pntd.0004088 relation, it is important to remember the symbiotic relationship between treatment and diagnostics. Treatments should only be administered when so indicated by differential diagnosis, and the pertinence of diagnostics depends on the available treatments. Currently, the most widely used method of diagnosis of snakebite envenoming is the syndromic approach (see Table 3). This approach can be highly effective, when the treating physician possesses sufficient knowledge on snakes and has been properly trained in providing correct differential diagnosis. Unfortunately, not all physicians possess this knowledge and expertise, and in some regions, utilization of the syndromic approach is challenging. If novel diagnostics could be implemented in such clinical settings, they could support the standardization of snakebite diagnosis. In combination with improved training of healthcare workers, this could in turn further improve standardization of treatment. Additional benefits could be reaped by using diagnostics to improve our knowledge of prevalence and inform the design of antivenoms and resource management.

\section{AUTHOR CONTRIBUTIONS}

$\mathrm{AL}, \mathrm{CK}$, and JJ conceptualized the manuscript. AH, CK, JJ, RF, $\mathrm{SF}$, and SD prepared the original draft. All authors contributed to the article and approved the submitted version.

\section{FUNDING}

We thank Innovation Fund Denmark (grant 9065-00007B) for financial support.
9. White J, Mahmood MA, Alfred S, Thwin KT, Kyaw KM, Zaw A, et al. A comprehensive approach to managing a neglected, neglected tropical disease; The Myanmar Snakebite Project (MSP). Toxicon X (2019) 1:100001. doi: 10.1016/j.toxcx.2018.100001

10. Mahmood MA, Halliday D, Cumming R, Thwin KT, Kyaw MMZ, White J, et al. Snakebite incidence in two townships in Mandalay Division, Myanmar. PloS Negl Trop Dis (2018) 12:1-12. doi: 10.1371/journal.pntd.0006643

11. Harrison RA, Hargreaves A, Wagstaff SC, Faragher B, Lalloo DG. Snake Envenoming: A disease of poverty. PloS Negl Trop Dis (2009) 3:e569. doi: 10.1371/journal.pntd.0000569

12. Chaves LF, Chuang T-W, Sasa M, Gutiérrez JM. Snakebites are associated with poverty, weather fluctuations, and El Niño. Sci Adv (2015) 1:e1500249e1500249. doi: 10.1126/sciadv.1500249

13. Pucca MB, Cerni FA, Janke R, Bermúdez-méndez E, Ledsgaard L, Barbosa JE, et al. History of Envenoming Therapy and Current Perspectives. Front Immunol (2019) 10:159. doi: 10.3389/fimmu.2019.0159

14. World Health Organization. Global snakebite burden. World Health Organization (2018). Available at: https://apps.who.int/gb/ebwha/pdf_files/ WHA71/A71_17-en.pdf.

15. Müller GJ, Modler H, Wium CA, Veale DJH. Snake bite in southern Africa: diagnosis and management. Contin Med Educ J (2012) 30:362-81. doi: 10.1111/j.1365-2923.1988.tb00427.x

16. World Health Organization. Guidelines for the production, control and regulation of snake antivenom immunoglobulins. (2018). Available at: https://www.who.int/bloodproducts/AntivenomGLrevWHO_TRS_1004_ web_Annex_5.pdf?ua=1. 
17. Rojnuckarin P. Clinical Uses of Snake Antivenoms. Clin Toxinol Asia Pacific Africa2 (2015) 2:437-52. doi: 10.1007/978-94-007-6386-9_24

18. White J. Venomous animals: clinical toxinology. In: A Luch, editor. Molecular, Clinical and Environmental Toxicology. Birkhäuser Verlag AG (2010). p. 233-91.

19. Wilkins D, Burns DS, Wilson D, Warrell DA, Lamb LEM. Snakebites in Africa and Europe: a military perspective and update for contemporary operations. J R Army Med Corps (2018) 164(5):370-9. doi: 10.1136/jramc2017-000883. jramc-2017-000883.

20. Calvete JJ, Sanz L, Cid P, de la Torre P, Flores-Díaz M, Dos Santos MC, et al. Snake Venomics of the Central American Rattlesnake Crotalus simus and the South American Crotalus durissus Complex Points to Neurotoxicity as an Adaptive Paedomorphic Trend along Crotalus Dispersal in South America. J Proteome Res (2010) 9:528-44. doi: 10.1021/pr9008749

21. Calvete JJ, Sanz L, Pérez A, Borges A, Vargas AM, Lomonte B, et al. Snake population venomics and antivenomics of Bothrops atrox: Paedomorphism along its transamazonian dispersal and implications of geographic venom variability on snakebite management. J Proteomics (2011) 74:510-27. doi: 10.1016/j.jprot.2011.01.003

22. Madrigal M, Sanz L, Flores-Díaz M, Sasa M, Núñez V, Alape-Girón A, et al. Snake venomics across genus Lachesis. Ontogenetic changes in the venom composition of Lachesis stenophrys and comparative proteomics of the venoms of adult Lachesis melanocephala and Lachesis acrochorda. J Proteomics (2012) 77:280-97. doi: 10.1016/j.jprot.2012.09.003

23. Chippaux J-P, Williams V, White J. Snake venom variability: methods of study, results and interpretation. Toxicon (1991) 29:1279-303. doi: 10.1016/ 0041-0101(91)90116-9

24. Muelling RJ, Samson RF, Beven T. The precipitin test in elucidating the cause of death. Am J Clin Pathol (1957) 28:489-94. doi: 10.1093/ajcp/ 28.5.489

25. Trethewie ER, Rawlinson PA. Immunological diagnosis of type of snake in snake-bite. Med J Aust (1967) 2:111-3. doi: 10.5694/j.1326-5377.1967. tb73915.x

26. Boche RD, Russell FE. Passive hemagglutination studies with snake venom and antivenin. Toxicon (1968) 6:125-7. doi: 10.1016/0041-0101(68)90031-7

27. Greenwood BM, Warrell DA, Davidson NM, Ormerod LD, Reid HA. Immunodiagnosis of Snake Bite. Br Med J (1974) 4:743-5. doi: 10.1136/ bmj.4.5947.743

28. Coulter AR, Sutherland SK, Broad AJ. Assay of snake venoms in tissue fluids. J Immunol Methods (1974) 4:297-300. doi: 10.1016/0022-1759(74)90072-6

29. Sutherland SK, Coulter AR, Broad AJ. Human snake bite victims: the successful detection of circulating snake venom by radioimmunoassay. Med J Aust (1975) 1:27-9. doi: 10.5694/j.1326-5377.1975.tb111208.x

30. Theakston RDG, Lloyd-Jones MJ, Reid HA. Micro-ELISA for detecting and assaying snake venom and venom-antibody. Lancet (1977) 2:639-41. doi: 10.1016/S0140-6736(77)92502-8

31. Sutherland SK, Coulter AR. Snake bite: detection of venom by radioimmunoassay. Med J Aust (1977) 12:683-4. doi: 10.5694/j.13265377.1977.tb99207.x

32. Sutherland SK, Coulter AR. Three instructive cases of tiger snake (Notechis scutatus) envenomation-and how a radioimmunoassay proved the diagnosis. Med J Aust (1977) 6:177-80. doi: 10.5694/j.1326-5377.1977. tb114543.x

33. Coulter AR, Fox JC, Sutherland SK, Waddell CJ. A new solid-phase sandwich radioimmunoassay and its application to the detection of snake venom. J Immunol Methods (1978) 23:241-52. doi: 10.1016/0022-1759(78) 90198-9

34. Coulter AR, Harris RD, Sutherland SK. Clinical Laboratory: Enzyme immunoassay for the rapid clinical detection of snake venom. Med J Aust (1980) 1:433-5. doi: 10.5694/j.1326-5377.1980.tb135003.x

35. Chandler HM, Hurrell JGR. A new enzyme immunoassay system suitable for field use and its application in a snake venom detection kit. Clin Chim Acta (1982) 121:225-30. doi: 10.1016/0009-8981(82)90062-6

36. Lwin KO, Myint AA. The use of enzyme-linked immunosorbent assay in detection of Russell's viper venom in body fluid. Snake (1983) 14:77-82.

37. Dhaliwal JS, Lim TW, Sukumaran KD. A double antibody sandwich microELISA kit for the rapid diagnosis of snake bite. Southeast Asian J Trop Med Public Heal (1983) 14:367-73.
38. Minton SA, Weinstein SA, Wilde CE3. An enzyme-linked immunoassay for detection of North American pit viper venoms. J Toxicol - Clin Toxicol (1984) 22:303-16. doi: 10.3109/15563658408992562

39. Lwin KO, Myint AA, Pe T, Nwe T, Naing M. Russell's viper venom levels in serum of snake bite victims in Burma. Trans R Soc Trop Med Hyg (1984) 78:165-8. doi: 10.1016/0035-9203(84)90267-0

40. Ho M, Warrell MJ, Warrell DA, Bidwell D, Voller A. A critical reappraisal of the use of enzyme-linked immunosorbent assays in the study of snake bite. Toxicon (1986) 24:211-21. doi: 10.1016/0041-0101(86)90147-9

41. Doellgast GJ. Enzyme-linked coagulation assay. Anal Biochem (1987) 167:97-105. doi: 10.1016/0003-2697(87)90137-0

42. Pugh RNH, Theakston RDG. A clinical study of viper bite poisoning. Ann Trop Med Parasitol (1987) 81:135-49. doi: 10.1080/00034983. 1987.11812106

43. Watt G, Wurzel WD, Theakston RDG. Postmortem immunodiagnosis of cobra bite in a Marine. Mil Med (1987) 152:209-10. doi: 10.1093/milmed/ 152.4.209

44. Silamut K, Ho M, Looareesuwan S, Viravan C, Wuthiekanun V, Warrell DA. Detection of venom by enzyme linked immunosorbent assay (ELISA) in patients bitten by snakes in Thailand. Br Med J (1987) 294:402-4. doi: $10.1136 / \mathrm{bmj} .294 .6569 .402$

45. Pukrittayakamee S, Ratcliffe PJ, McMichael AJ, Warrell DA, Bunnag D. A competitive radioimmunoassay using a monoclonal antibody to detect the factor X activator of Russell's viper venom. Toxicon (1987) 25:721-9. doi: 10.1016/0041-0101(87)90122-X

46. Labrousse H, Nishikawa AK, Boni C, Avrameas S. Development of a rapid and sensitive enzyme-linked immunosorbent assay (ELISA) for measuring venom antigens after an experimental snake bite. Toxicon (1988) 26:115767. doi: 10.1016/0041-0101(88)90300-5

47. Watanabe M, Sakai A, Kouda T, Sawai Y. Detection of Agkistrodon blomhoffi blomhoffi venom in serum of mice ny enzyme-linked immunosorbent assay (ELISA). Snake (1988) 20:25-9.

48. Barral-Netto M, Schriefer A, Vinhas V, Almeida AR. Enzyme-linked immunosorbent assay for the detection of Bothrops jararaca venom. Toxicon (1990) 28:1053-61. doi: 10.1016/0041-0101(90)90143-U

49. Hatsuse M, Sakai A, Sawai Y. Detection and quantitative assay of Agkistrodon blomhoffi blomhoffi venom and antivenom by enzyme-linked immunosorbent assay (ELISA) with special reference to in-vivo effect of the antivenom. Snake (1990) 22:20-7.

50. Chinonavanig L, Karnchanachetanee C, Pongsettakul P, Ratanabanangkoon K. Diagnosis of snake venoms by a reverse latex agglutination test. J Clin Toxicol (1991) 29:493-503. doi: 10.3109/15563659109025746

51. Barral-Netto M, von Sohsten RL. Serum kinetics of crotoxin from Crotalus durissus terrificus venom in mice: evidence for a rapid clearance. Toxicon (1991) 29:527-31. doi: 10.1016/0041-0101(91)90028-P

52. Tun-Pe, Ba-Aye, Aye-Aye-Myint, Tin-Nu-Swe, Warrell DA. Bites by Russell's vipers (Daboia russelii siamensis) in Myanmar: effect of the snake's length and recent feeding on venom antigenaemia and severity of envenoming. Trans R Soc Trop Med Hyg (1991) 85:804-8. doi: 10.1016/ 0035-9203(91)90464-A

53. Audebert F, Sorkine M, Bon C. Envenoming by viper bites in France: Clinical gradation and biological quantification by ELISA. Toxicon (1992) 30:599609. doi: 10.1016/0041-0101(92)90854-X

54. Audebert F, Grosselet O, Sabouraud A, Bon C. Quantitation of Venom Antigens from European Vipers in Human Serum or Urine by ELISA. J Anal Toxicol (1993) 17:236-40. doi: 10.1093/jat/17.4.236

55. Audebert F, Sorkine M, Robbe-Vincent A, Bon C. Viper bites in France: Clinical and biological evaluation; Kinetics of envenomations. Hum Exp Toxicol (1994) 13:683-8. doi: 10.1177/096032719401301006

56. Audebert F, Urtizberea M, Sabouraud A, Scherrmann JM, Bon C. Pharmacokinetics of Vipera aspis venom after experimental envenomation in rabbits. J Pharmacol Exp Ther (1994) 268:1512-7.

57. Cox JC, Moisidis AV, Shepherd JM, Drane DP, Jones SL. A novel format for a rapid sandwich EIA and its application to the identification of snake venoms. J Immunol Methods (1992) 146:213-8. doi: 10.1016/0022-1759(92) 90230-Q

58. Tan NH, Yeo KH, Nik Jaafar MI. The use of enzyme-linked immunosorbent assay for the quantitation of Calloselasma rhodostoma (Malayan pit viper) 
venom and venom antibodies. Toxicon (1992) 30:1609-20. doi: 10.1016/ 0041-0101(92)90033-2

59. Kittigul L, Ratanabanangkoon K. Reverse passive hemagglutination tests for rapid diagnosis of snake envenomation. J Immunoassay (1993) 14:105-27. doi: 10.1080/15321819308019844

60. Heneine LGD, Catty D. Species-specific detection of venom antigens from snakes of the Bothrops and Lachesis genera. Toxicon (1993) 31:591-603. doi: 10.1016/0041-0101(93)90114-X

61. Chavez-Olortegui C, Lopes CS, Cordeiro FD, Granier C, Diniz CR. An enzyme linked immunosorbent assay (ELISA) that discriminates between Bothrops atrox and Lachesis muta muta venoms. Toxicon (1993) 31:417-26. doi: 10.1016/0041-0101(93)90177-K

62. Bhatti AR, Wong JP, Siddiqui YM, Siddiqui S. A sensitivte fluorogenic enzyme linked immunosorbent assay for the detection of Vipera russelli venom. Nat Toxins (1993) 1:277-82. doi: 10.1002/nt.2620010504

63. Lalloo D, Trevett A, Black J, Mapao J, Naraqi S, Owens D, et al. Neurotoxicity and haemostatic disturbances in patients envenomed by the Papuan black snake (Pseudechis papuanus). Toxicon (1994) 32:927-36. doi: 10.1016/0041-0101(94)90371-9

64. Gillissen A, Theakston RDG, Barth J, May B, Krieg M, Warrell DA. Neurotoxicity, haemostatic disturbances and haemolytic anaemia after a bite by a Tunisian saw-scaled or carpet viper (Echis "pyramidum"-complex): Failure of antivenom treatment. Toxicon (1994) 32:937-44. doi: 10.1016/ 0041-0101(94)90372-7

65. Li Q, Ownby CL. Development of an enzyme-linked immunosorbent assay (ELISA) for identification of venoms from snakes in the Agkistrodon genus. Toxicon (1994) 32:1315-25. doi: 10.1016/0041-0101(94)90404-9

66. Pe T, Myint AA, Warrell DA, Myint T. King cobra (Ophiophagus hannah) bites in Myanmar: Venom antigen levels and development of venom antibodies. Toxicon (1995) 33:379-82. doi: 10.1016/0041-0101(94)00157-4

67. Sjostrom L, Karlson-Stiber C, Persson H, Al-Abdulla IH, Smith DC. Development and clinical application of immunoassays for European adder (Vipera berus berus) venom and antivenom. Toxicon (1996) 34:918. doi: 10.1016/0041-0101(95)00110-7

68. De AK. Development of an immunodiagnostic kit for species identification of snakebite and studies on the cross-reacting venom antigens [Ph.D. thesis]. Bangalore; Indian Institute of Science. (1996). Available at: https://etd.iisc.ac. in/static/etd/abstracts/3956/G14544-Abs.pdf.

69. Bucher B, Canonge D, Thomas L, Tyburn B, Robbe-Vincent A, Choumet V, et al. Clinical indicators of envenoming and serum levels of venom antigens in patients bitten by Bothrops lanceolatus in Martinique. Trans $R$ Soc Trop Med Hyg (1997) 91:186-90. doi: 10.1016/S0035-9203(97)90219-4

70. Amuy E, Alape-Girón A, Lomonte B, Thelestam M, Gutiérrez JM. Development of immunoassays for determination of circulating venom antigens during envenomations by coral snakes (Micrurus species). Toxicon (1997) 35:1605-16. doi: 10.1016/S0041-0101(97)00045-7

71. Selvanayagam ZE, Gnanavendhan SG, Ganesh KA, Rajagopal D, Rao PV. ELISA for the detection of venoms from four medically important snakes of India. Toxicon (1999) 37:757-70. doi: 10.1016/S0041-0101(98)00215-3

72. Huang YP, Yu YJ, Hung D-Z. Sandwich enzyme-linked immunosorbent assay for Taiwan cobra venom. Vet Hum Toxicol (2002) 44:200-2009.

73. Dong LV, Selvanayagam ZE, Gopalakrishnakone P, Eng KH. A new avidinbiotin optical immunoassay for the detection of beta-bungarotoxin and application in diagnosis of experimental snake envenomation. J Immunol Methods (2002) 260:125-36. doi: 10.1016/S0022-1759(01)00527-0

74. Lión V, Rojas A, Rodriguez-Acosta A. Design of an agglutination latex test to detect venoms from viperidae snakes in patients' serum. Rev Cuba Med Trop (2004) 56:13-20.

75. Van Dong L, Khoo HE, Quyen LK, Gopalakrishnakone P. Optical immunoassay for snake venom detection. Biosens Bioelectron (2004) 19:1285-94. doi: 10.1016/j.bios.2003.11.020

76. Brunda G, Sashidhar RB, Sarin RK. Use of egg yolk antibody (IgY) as an immunoanalytical tool in the detection of Indian cobra (Naja naja naja) venom in biological samples of forensic origin. Toxicon (2006) 48:183-94. doi: 10.1016/j.toxicon.2006.04.011

77. Brunda G, Sashidhar RB. Epidemiological profile of snake-bite cases from Andhra Pradesh using immunoanalytical approach. Indian J Med Res (2007) 125:661-5.
78. Gao R, Zhang Y, Gopalakrishnakone P. Immuno-fluorescence detection of snake venom by using single bead as the assay platform. J Exp Nanosci (2008) 3:111-9. doi: 10.1080/17458080701713953

79. Kulawickrama S, O'Leary MA, Hodgson WC, Brown SGA, Jacoby T, Davern $\mathrm{K}$, et al. Development of a sensitive enzyme immunoassay for measuring taipan venom in serum. Toxicon (2010) 55:1510-8. doi: 10.1016/ j.toxicon.2010.03.003

80. Núñez Rangel V, Fernández Culma M, Rey-suárez P, Pereañez JA. Development of a sensitive enzyme immunoassay (ELISA) for specific identification of Lachesis acrochorda venom. J Venom Anim Toxins Incl Trop Dis (2012) 18:173-9. doi: 10.1590/S1678-91992012000200007

81. Ibrahim NM, El-Kady EM, Katamesh RA, El-Borei IH, Wahby AF. Identification and discrimination of snake venoms from Egyptian elapids. Toxicon (2013) 63:88-97. doi: 10.1016/j.toxicon.2012.11.020

82. Hung D-Z, Lin J-H, Mo JF, Huang CF, Liau MY. Rapid diagnosis of Naja atra snakebites. Clin Toxicol (2014) 52:187-91. doi: 10.3109/15563650. 2014.887725

83. Pawade BS, Salvi NC, Shaikh IK, Waghmare AB, Jadhav ND, Wagh VB, et al. Rapid and selective detection of experimental snake envenomation - Use of gold nanoparticle based lateral flow assay. Toxicon (2016) 119:299-306. doi: 10.1016/j.toxicon.2016.10.009

84. Shaikh IK, Dixit PP, Pawade BS, Waykar IG. Development of dot-ELISA for the detection of venoms of major Indian venomous snakes. Toxicon (2017) 139:66-73. doi: 10.1016/j.toxicon.2017.10.007

85. Liu CC, Yu JS, Wang PJ, Hsiao YC, Liu CH, Chen YC, et al. Development of sandwich ELISA and lateral flow strip assays for diagnosing clinically significant snakebite in Taiwan. PloS Negl Trop Dis (2018) 12:1-23. doi: 10.1371/journal.pntd.0007014

86. Faria RAD, Lins V de F, Nappi GU, Matencio T, Heneine LGD. Development of an Impedimetric Immunosensor for Specific Detection of Snake Venom. Bionanoscience (2018) 8:988-96. doi: 10.1007/s12668-0180559-7 and 10.1007/12668.2191-1649

87. Maduwage KP, Gawarammana IB, Gutiérrez JM, Kottege C, Dayaratne R, Premawardena NP, et al. Enzyme immunoassays for detection and quantification of venoms of Sri Lankan snakes: Application in the clinical setting. PloS Negl Trop Dis (2020) 14:1-17. doi: 10.1371/journal.pntd. 0008668

88. Lin J-H, Lo C-M, Chuang S-H, Chiang C-H, Wang S-D, Lin TY, et al. Collocation of avian and mammal antibodies to develop a rapid and sensitive diagnostic tool for Russell's vipers snakebite. PloS Negl Trop Dis (2020) 14:119. doi: 10.1371/journal.pntd.0008701

89. Lin J-H, Sung W, Liao J, Hung D-Z. A Rapid and International Applicable Diagnostic Device for Cobra (Genus Naja) Snakebites. Toxins (Basel) (2020) 12:1-14. doi: 10.3390/toxins12090572

90. Suntrarachun S, Pakmanee N, Tirawatnapong T, Chanhome L, Sitprija V. Development of a polymerase chain reaction to distinguish monocellate cobra (Naja khouthia) bites from other common Thai snake species, using both venom extracts and bite-site swabs. Toxicon (2001) 39:1087-90. doi: 10.1016/S0041-0101(00)00246-4

91. Supikamolseni A, Ngaoburanawit N, Sumnotha M, Chanhome L, Suntrarachun S, Peyachoknagul S, et al. Molecular barcoding of venomous snakes and species-specific multiplex PCR assay to identify snake groups for which antivenom is available in Thailand. Genet Mol Res (2015) 14:13981-97. doi: 10.4238/2015.October.29.18

92. Sharma SK, Kuch U, Hoede P, Brunhse L, Pandey DP, Ghimire A, et al. Use of Molecular Diagnostic Tools for the Identification of Species Responsible for Snakebite in Nepal: A Pilot Study. PloS Negl Trop Dis (2016) 10: e0004620. doi: 10.1371/journal.pntd.0004620

93. Maduwage K, O'Leary MA, Isbister GK. Diagnosis of snake envenomation using a simple phospholipase A2 assay. Sci Rep (2014) 4:1-4. doi: 10.1038/ srep0 4827

94. de Medeiros CR, Brioschi ML, de Souza SN, Teixeira MJ. Infrared thermography to diagnose and manage venomous animal bites and stings. Rev Soc Bras Med Trop (2017) 50:260-4. doi: 10.1590/0037-86820390-2016

95. Isbister GK, Mirajkar N, Fakes K, Brown SGA, Veerati PC. Phospholipase A2 (PLA2) as an early indicator of envenomation in elapid snakebites (ASP27). Clin Toxicol (2018) 56:919-20. doi: 10.1080/15563650.2018.1506610 
96. Chippaux JP, Theakston RD. Epidemiological studies of snake bite in French Guiana. Ann Trop Med Parasitol (1987) 81:301-4. doi: 10.1080/ 00034983.1987.11812123

97. Pugh RNH, Theakston RDG. Incidence and mortality of snakebite in Savanna Nigeria. Lancet (1980) 2:1181-3. doi: 10.1016/S0140-6736(80) 92608-2

98. Theakston RDG, Pugh RNH, Reid HA. Enzyme-linked immunosorbentassay of venom-antibodies in human victims of snake bite. J Trop Med Hyg (1981) 84:109-12.

99. Bober MA, Glenn JL, Straight RC, Ownby CL. Detection of myotoxin a-like proteins in various snake venoms. Toxicon (1988) 26:665-73. doi: 10.1016/ 0041-0101(88)90248-6

100. Bober MA, Ownby CL. Use of affinity-purified antibodies to measure the in vivo disappearance of antibodies to myotoxin a. Toxicon (1988) 26:301-8. doi: 10.1016/0041-0101(88)90221-8

101. Alape-Giron A, Stiles BG, Gutierrez JM. Antibody-mediated neutralization and binding-reversal studies on $\alpha$-neurotoxins from Micrurus nigrocinctus nigrocinctus (coral snake) venom. Toxicon (1996) 34:369-80. doi: 10.1016/ 0041-0101(95)00126-3

102. Stiles BG. A non-radioactive receptor assay for snake venom postsynaptic neurotoxins. Toxicon (1991) 29:503-10. doi: 10.1016/0041-0101(91)90024-L

103. Lomonte B, Gutiérrez J, Romero M, Núñez J, Tarkowski A, Hanson LÅ. An MTT-based method for the in vivo quantification of myotoxic activity of snake venoms and its neutralization by antibodies. J Immunol Methods (1993) 161:231-7. doi: 10.1016/0022-1759(93)90299-M

104. Laustsen AH, Engmark M, Milbo C, Johannesen J, Lomonte B, Gutiérrez JM, et al. From Fangs to Pharmacology: The Future of Antivenoms. Curr Pharm Des (2016) 9:5270-93. doi: 10.2174/1381612822666160623073438

105. Laustsen AH, Solà M, Jappe EC, Oscoz S, Lauridsen LP, Engmark M. Biotechnological trends in spider and scorpion antivenom development. Toxins (Basel) (2016) 8:226. doi: 10.3390/toxins8080226

106. Knudsen C, Laustsen AH. Recent Advances in Next Generation Snakebite Antivenoms. Trop Med Infect Dis (2018) 3:42. doi: 10.3390/ tropicalmed 3020042

107. Laustsen AH, Karatt-Vellatt A, Masters EW, Arias AS, Pus U, Knudsen C, et al. In vivo neutralization of dendrotoxin-mediated neurotoxicity of black mamba (Dendroaspis polylepis) venom by mixtures of human IgG monoclonal antibodies. Nat Commun (2018) 9:3928. doi: 10.1038/s41467018-06086-4

108. Albulescu L-O, Xie C, Ainsworth S, Alsolaiss J, Crittenden E, Dawson CA, et al. A therapeutic combination of two small molecule toxin inhibitors provides broad preclinical efficacy against viper snakebite. Nat Commun (2020) 11:1-14. doi: 10.1038/s41467-020-19981-6

109. White J. A Clinician's Guide to Australian Venomous Bites and Stings: incorporating the updated CSL antivenom handbook. (2013). Available at: https://biomedicalsciences.unimelb.edu.au/:data/assets/pdf_file/0004/ 3216739/A-Clinicians-Guide-to-Venomous-Bites-and-Stings-2013.pdf.

110. Lavonas EJ, Ruha AM, Banner W, Bebarta V, Bernstein JN, Bush SP, et al. Unified treatment algorithm for the management of crotaline snakebite in the United States: Results of an evidence-informed consensus workshop. BMC Emerg Med (2011) 11:2. doi: 10.1186/1471-227X-11-2

111. Orduna TA, Lloveras SC, de Roodt AR, Garcia SI, Haas AI, Moreno I, et al. Guía de Prevención, Diagnóstico, Tratamiento y Vigilancia Epidemiológica de los Envenenamientos Ofidicos. Buenos Aires (2007). Available at: http://www. afam.org.ar/articulos\%20sitio\%20web\%202016/ofidismo.pdf.

112. Bolon I, Durso AM, Mesa SB, Ray N, Alcoba G, Chappuis F, et al. Identifying the snake: First scoping review on practices of communities and healthcare providers confronted with snakebite across the world. PloS One (2020) 15:124. doi: 10.1371/journal.pone.0229989

113. Harris JB, Faiz MA, Rahman MR, Jalil MM, Ahsan MF, Theakston RDG, et al. Snake bite in Chittagong Division, Bangladesh: A study of bitten patients who developed no signs of systemic envenoming. Trans $R$ Soc Trop Med Hyg (2010) 104:320-7. doi: 10.1016/j.trstmh.2009.12.006

114. White J, Alfred S, Bates D, Mahmood MA, Warrell DA, Cumming R, et al. Twelve month prospective study of snakebite in a major teaching hospital in Mandalay, Myanmar; Myanmar Snakebite Project (MSP). Toxicon X (2018) 1:100002. doi: 10.1016/j.toxcx.2018.100002
115. Joseph JK, Simpson ID, Menon NCS, Jose MP, Kulkarni KJ, Raghavendra GB, et al. First authenticated cases of life-threatening envenoming by the hump-nosed pit viper (Hypnale hypnale) in India. Trans R Soc Trop Med Hyg (2007) 101:85-90. doi: 10.1016/j.trstmh.2006.03.008

116. Isbister GK, Brown SGA, Page CB. Snakebite in Australia: a practical approach to diagnosis and treatment. Med J Aust (2013) 199:763-8. doi: $10.5694 / \mathrm{mja} 12.11172$

117. Ireland G, Brown SGA, Buckley NA, Stormer J, Currie BJ, White J, et al. Changes in serial laboratory test results in snakebite patients: when can we safely exclude envenoming? Med J Aust (2010) 193:285-90. doi: 10.5694/ j.1326-5377.2010.tb03909.x

118. Isbister GK. Snake bite: A current approach to management. Aust Prescr (2006) 29:156-8. doi: 10.18773/austprescr.2006.095

119. Welton RE, Williams DJ, Liew D. Injury trends from envenoming in Australia, 2000-2013. Intern Med J (2016) 47:170-6. doi: 10.1111/imj.13297

120. Welton RE, Liew D, Braitberg G. Incidence of fatal snakebite in Australia: A coronial based retrospective study (2000-2016). Toxicon (2017) 131:11-5. doi: 10.1016/j.toxicon.2017.03.008

121. Johnston CI, Ryan NM, Page CB, Buckley NA, Brown SGA, O’Leary MA, et al. The Australian snakebite project, 2005-2015 (ASP-20). Med J Aust (2017) 207:119-25. doi: 10.5694/mja17.00094

122. Steuten J, Winkel K, Carroll T, Williamson NA, Ignjatovic V, Fung K, et al. The molecular basis of cross-reactivity in the Australian Snake Venom Detection Kit (SVDK). Toxicon (2007) 50:1041-52. doi: 10.1016/ j.toxicon.2007.07.023

123. Nimorakiotakis V, Winkel KD. Prospective assessment of the false positive rate of the Australian snake venom detection kit in healthy human samples. Toxicon (2016) 111:143-6. doi: 10.1016/j.toxicon.2015.12.002

124. Weinstein SA, Mirtschin PJ, White J. Risks and realities of single vial antivenom recommendations for envenoming by Australian elapid snakes. Med J Aust (2019) 211:492-3. doi: 10.5694/mja2.50314

125. Johnston CI, Brown SGA, O'Leary MA, Currie BJ, Greenberg R, Taylor M, et al. Mulga snake (Pseudechis australis) envenoming: A spectrum of myotoxicity, anticoagulant coagulopathy, haemolysis and the role of early antivenom therapy-Australian Snakebite Project (ASP-19). Clin Toxicol (2013) 51:417-24. doi: 10.3109/15563650.2013.787535

126. Johnston CI, Ryan NM, O'Leary MA, Brown SGA, Isbister GK. Australian taipan (Oxyuranus spp.) envenoming: clinical effects and potential benefits of early antivenom therapy-Australian Snakebite Project (ASP-25). Clin Toxicol (2017) 55:115-22. doi: 10.1080/15563650.2016.1250903

127. Joseph JK. Viperidae Envenomation in India. In: Gopalakrishnakone P, Faiz A, Fernando R, Gnanathasan C, Habib A and Yang CC, editors. Toxinology: Clinical Toxinology in Asia Pacific and Africa, vol 2. Springer: Dordecht (2015). pp. 191-208. doi: 10.1007/978-94-007-6386-9_40

128. de Silva HJ, Gunatilake SB, Kularatne SA, Sellahewa KH. Anti-venom for snakebite in Sri Lanka. Ceylon Med J (2011) 47:43-5. doi: 10.4038/ cmj.v47i2.3449

129. Chanhome L, Cox MJ, Wilde H, Jintakoon P, Chaiyabutr N, Sitprija V. Venomous snakebite in Thailand. I: Medically important snakes. Mil Med (1998) 163:310-7. doi: 10.1093/milmed/163.5.310

130. Okamoto O, Suzuki R, Kusatsu M, Nakashima R, Inagaki N, Kai Y, et al. Mamushi (Gloydius blomhoffii) Snake Bites in Japan - Current Problems and Clues to a Solution. J Pharmacol Clin Toxicol (2018) 6:1103.

131. Rha JJ, Kwon SM, Oh JR, Han BK, Lee KH, Kim JH. Snakebite in Korea: A Guideline to Primary Surgical Management. Yonsei Med J (2015) 56:1443-8. doi: $10.3349 / y m j .2015 .56 .5 .1443$

132. Fung HTJ, Lam SKT, Kam CW, Simpson ID. A survey of Snakebite Management Knowledge Amongst Select Physicians in Hong Kong and the Implications for Snakebite Training. Wilderness Environ Med (2009) 20:364-70. doi: 10.1580/1080-6032-020.004.0364

133. Mao Y-C, Hung D-Z. Epidemiology of snake envenomation in Taiwan. Clin Toxinol Asia Pacific Afr (2015), 3-22. doi: 10.1007/978-94-007-6386-9_45

134. Adiwinata R, Nelwan EJ. Snakebite in Indonesia. Acta Med Indones (2015) 47:358-65.

135. Alirol E, Sharma SK, Bawaskar HS, Kuch U, Chappuis F. Snake bite in south asia: A review. PloS Negl Trop Dis (2010) 4:e603. doi: 10.1371/ journal.pntd.0000603 
136. World Health Organization. WHO/SEARO Guidelines for the clinical management of snake bites in the South-East Asia Region. Southeast Asian J Trop Med Public Health (1999) 30 Suppl 1:1-85.

137. World Health Organization. Guidelines for the Clinical Management of Snake bites in the South-East Asia Region. Southeast Asian J Trop Med Public Health (2005) 30:1-85.

138. Ghose A, White J. Asian Snakes. In: Brent J, Burkhart K, Dargan P, Hatten B, Megarbane B, Palmer R, et al, editors. Critical Care Toxicology: Diagnosis and Management of the Critically Poisoned Patient. New York:Springer International Publishing (2017). p. 2343-403. doi: 10.1007/978-3-319$17900-1$

139. Rojnuckarin P, Suteparak S, Sibunruang S. Diagnosis and management of venomous snakebites in Southeast Asia. Asian BioMed (2012) 6:795-805. doi: 10.5372/1905-7415.0606.125

140. Prasarnpun S, Walsh J, Awad SS, Harris JB. Envenoming bites by kraits: the biological basis of treatment-resistant neuromuscular paralysis. Brain (2005) 128:2987-96. doi: 10.1093/brain/awh642

141. Theakston RDG, Phillips RE, Warrell DA, Galagedera Y, Abeysekera DTDJ, Dissanayaka P, et al. Envenoming by the common krait (Bungarus caeruleus) and Sri lankan cobra (Naja naja naja): Efficacy and complications of therapy with haffkine antivenom. Trans R Soc Trop Med Hyg (1990) 84:301-8. doi: 10.1016/0035-9203(90)90297-R

142. Mondal R, Chowdhury F, Rani M, Mohammad N, Monjurul Islam M, Ashraful Haque M, et al. Pre-hospital and Hospital Management Practices and Circumstances behind Venomous Snakebite in Northwestern Part of Bangladesh. Asia Pacific J Med Toxicol (2012) 1:18-21.

143. Pathmeswaran A, Kasturiratne A, Fonseka M, Nandasena S, Lalloo DG, de Silva HJ. Identifying the biting species in snakebite by clinical features: an epidemiological tool for community surveys. Trans $R$ Soc Trop Med Hyg (2006) 100:874-8. doi: 10.1016/j.trstmh.2005.10.003

144. Suraweera W, Warrell D, Whitaker R, Menon GR, Rodrigues R, Fu SH, et al. Trends in snakebite deaths in India from 2000 to 2019 in a nationally representative mortality study. Elife (2020) 9:e54076. doi: 10.7554/ eLife.54076

145. Whitaker R, Whitaker S. Venom, antivenom production and the medically important snakes of India. Curr Sci (2012) 103:635-43.

146. Gupt A, Bhatnagar T, Murthy BN. Epidemiological profile and management of snakebite cases - A cross sectional study from Himachal Pradesh, India. Clin Epidemiol Glob Heal (2015) 3:S96-S100. doi: 10.1016/j.cegh.2015.11.007

147. Menon JC, Joseph JK, Jose MP, Punde D, Mazumdar DB, Bawaskar HS, et al. Management protocol of venomous snakebite in India: a consensus statement. Toxin Rev (2016) 35:147-51. doi: 10.1080/15569543. 2016.1185735

148. Ariaratnam CA, Thuraisingam V, Kularatne SAM, Sheriff MHR, Theakston RDG, de Silva A, et al. Frequent and potentially fatal envenoming by humpnosed pit vipers (Hypnale hypnale and H. nepa) in Sri Lanka: lack of effective antivenom. Trans R Soc Trop Med Hyg (2008) 102:1120-6. doi: 10.1016/ j.trstmh.2008.03.023

149. Sellahewa KH, Gunawardena G, Kumararatne MP. Efficacy of antivenom in the treatment of severe local envenomation by the hump-nosed viper (Hypnale hypnale). Am J Trop Med Hyg (1995) 53:260-2. doi: 10.4269/ ajtmh.1995.53.260

150. Villalta M, Sánchez A, Herrera M, Vargas M, Segura Á, Cerdas M, et al. Development of a new polyspecific antivenom for snakebite envenoming in Sri Lanka: Analysis of its preclinical efficacy as compared to a currently available antivenom. Toxicon (2016) 122:152-9. doi: 10.1016/ j.toxicon.2016.10.007

151. Rosenfeld G. Symptomatology, Pathology, and Treatment of Snake Bites in South America. In: Wolfgang B, Buckley EE, editors. Venomous Animals and Their Venoms, Vol. Ii. Venomous Vertebrates. Xxiv + 687p. Illus. Maps. New York, NY, USA; London, England: Academic Press (1971). pp. 345-84.

152. Langley RL. Animal-related fatalities in the United States - an update. Wilderness Environ Med (2005) 16:67-74. doi: 10.1580/1080-6032(2005)16 [67:AFITUS]2.0.CO;2

153. O'Neil ME, Mack KA, Wozniak EJ. Snakebite injuries treated in United States emergency departments, 2001-2004. Wilderness Environ Med (2007) 18:281-7. doi: 10.1580/06-WEME-OR-080R1.1
154. Graham DC, Dickinson GT, Godden JO, Kelly AD, Randall RL, Wells TL. Snake Bites in Canada. Can Med Assoc J (1964) 90:1472-3.

155. Russell FE. Snake Venom Poisoning. Annu Rev Med (1980) 31:247-59. doi: 10.1016/B978-0-323-04107-2.50231-3

156. Curry SC, Horning D, Brady P, Requa R, Kunkel DB, Vance MV. The legitimacy of rattlesnake bites in Central Arizona. Ann Emerg Med (1989) 18:658-63. doi: 10.1016/S0196-0644(89)80523-2

157. Kitchens CS. Hemostatic aspects of envenomation by North-American snakes. Hematol Clin North Am (1992) 6:1189-95. doi: 10.1016/S08898588(18)30304-6

158. Hutton RA, Warrell DA. Action of snake venom components on the haemostatic system. Blood Rev (1993) 7:176-89. doi: 10.1016/0268-960X (93)90004-N

159. Bush SP, Siedenburg E. Neurotoxicity associated with suspected sourthern Pacific rattlesnake (Crotalus viridis helleri) envenomation. Wilderness Environ Med (1999) 10:247-9. doi: 10.1580/1080-6032(1999)010[0247: NAWSSP]2.3.CO;2

160. Richardson WH, Goto CS, Gutglass DJ, Williams SR, Clark RF. Rattlesnake envenomation with neurotoxicity refractory to treatment with crotaline Fab antivenom. Clin Toxicol (2007) 45:472-5. doi: 10.1080/15563650701338187

161. Clark RF, Williams SR, Nordt SP, Boyer-Hassen LV. Successful treatment of crotalid-induced neurotoxicity with a new polyspecific crotalid Fab antivenom. Ann Emerg Med (1997) 30:54-7. doi: 10.1016/S0196-0644(97) 70111-2

162. Wyeth Laboratories Inc. Antivenin (Micrurus fulvius) North American Coral Snake Antivenin. (2001). pp. 1-9. Available at: https://www.fda.gov/media/ 82301/download

163. Davidson TM, Eisner J. United States coral snakes. Wilderness Environ Med (1996) 7:38-45. doi: 10.1580/1080-6032(1996)007[0038:USCS]2.3.CO;2

164. Kitchens CS, Van Mierop LH. Envenomation by the Eastern coral snake (Micrurus fulvius fulvius). A study of 39 victims. JAMA J Am Med Assoc (1987) 258:1615-8. doi: 10.1001/jama.258.12.1615

165. Tan NH, Ponnudurau G. The biological properties of venoms of some American coral snakes (Genus Micrurus). Comp Biochem Physiol - Part B Comp Biochem (1992) 101:471-4. doi: 10.1016/0305-0491(92)90029-Q

166. Campbell CH. Symptomatology, Pathology and Treatment of the Bites of Elapid Snakes. In: CY, editor. Snake Venoms. Handbook of Experimental Pharmacology (Continuation of Handbuch der experimentellen Pharmakologie), vol 52. Berlin, Heidelberg: Springer (1979). pp. 888-9. doi: 10.1007/978-3-642-66913-2_24

167. Eagle H. The coagulation of blood by snake venoms and its physiologic significance. J Exp Med (1937) 65:613-39. doi: 10.1084/jem.65.5.613

168. Sanchez EF, Freitas TV, Ferreira-Alves DL, Velarde DT, Diniz MR, Cordeiro $\mathrm{MN}$, et al. Biological activities of venoms from South American snakes. Toxicon (1992) 30:97-103. doi: 10.1016/0041-0101(92)90505-Y

169. U.S. Food and Drug Administration. Expiration Date Extension for North American Coral Snake Antivenin (Micrurus fulvius) (Equine Origin) Lot L67530 through January 31, 2019. FDA.gov. (2018). Available at: https:// www.fda.gov/vaccines-blood-biologics/safety-availability-biologics/ expiration-date-extension-north-american-coral-snake-antivenin-micrurusfulvius-equine-origin-lot-0 (Accessed February 25, 2020).

170. Cox RD, Parker CS, Cox ECE, Marlin MB, Galli RL. Misidentification of copperhead and cottonmouth snakes following snakebites. Clin Toxicol (2018) 56:1195-9. doi: 10.1080/15563650.2018.1473583

171. Bush SP, Ruha AM, Seifert SA, Morgan DL, Lewis BJ, Arnold TC, et al. Comparison of $\mathrm{F}(\mathrm{ab}$ ')2 versus Fab antivenom for pit viper envenomation: $\mathrm{A}$ prospective, blinded, multicenter, randomized clinical trial. Clin Toxicol (2015) 53:37-45. doi: 10.3109/15563650.2014.974263

172. Gerardo CJ, Quackenbush E, Lewis B, Rutherfoord RS, Greene S, Toschlog EA, et al. The Efficacy of Crotalidae Polyvalent Immune Fab (Ovine) Antivenom Versus Placebo Plus Optional Rescue Therapy on Recovery From Copperhead Snake Envenomation: A Randomized, Double-Blind, Placebo-Controlled, Clinical Trial. Ann Emerg Med (2017) 70:233-44. doi: 10.1016/j.annemergmed.2017.04.034

173. Freiermuth CE, Lavonas EJ, Anderson VE, Kleinschmidt KC, Sharma K, Rapp-Olsson M, et al. Antivenom Treatment Is Associated with Fewer Patients using Opioids after Copperhead Envenomation. West J Emerg Med (2019) 20:497-505. doi: 10.5811/westjem.2019.3.42693 
174. Anderson VE, Gerardo CJ, Rapp-Olsson M, Bush SP, Mullins ME, Greene S, et al. Early administration of Fab antivenom resulted in faster limb recovery in copperhead snake envenomation patients. Clin Toxicol (2018) 0:1-6. doi: $10.1080 / 15563650.2018 .1491982$

175. Instituto Clodomiro Picado. Envenenamiento Por Mordedura De Serpiente En Centro América. San José, Universidad de Costa Rica (2013). doi: 10.1021/ jp980047v

176. Funasa. Manual de Diagnóstico e Tratamento de Acidentes por Animais Peçonhentos. Brasília, Funasa, Brazil (the Brazilian Ministry of Health) (2001).

177. Laustsen AH, Gutiérrez JM, Knudsen C, Johansen KH, Méndez EB, Cerni FA, et al. Pros and cons of different therapeutic antibody formats for recombinant antivenom development. Toxicon (2018) 146:151-75. doi: 10.1016/j.toxicon.2018.03.004

178. Personas DGDSDL-DEDAIDS. Norma Técnica sobre Prevención y Tratamiento de Accidentes por Animales Ponzoñosos. Lima: Minesterio de Salud, Peru (the Peruvian Ministry of Health) (2005). Available at: http:// www.essalud.gob.pe/downloads/guias_emergencia_epidemiologica/ normas_animales_ponzonosos.pdf.

179. Dirección de normatización del sistema nacional de salud. Manual de normas $y$ procedimientos sobre prevención y tratamiento de accidentes ocasionados por morderura de serpientes. Quito: Ministerio de Salud Pública del Ecuador (Ministry of Health, Ecuador) (2008). Available at: https://aplicaciones.msp. gob.ec/salud/archivosdigitales/documentosDirecciones/dnn/archivos/ MANUAL\%20DE\%20NORMAS\%20PROCEDIM.\%20PREVENC. MORDEDURA\%20DE\%20\%20SERPIENTES(1).pdf.

180. Centro de Información Toxicológica de Veracruz. Guía de diagnóstico y tratamiento de intoxicación por accidente ofidico crotálico. Veracruz. Available at: https://docplayer.es/7320740-Guia-de-diagnostico-ytratamiento-de-intoxicacion-por-accidente-ofidico-crotalico.html.

181. Marques HO, de Brito Sousa JD, Fan HW, de Oliveira SS, Guimarães de Lacerda MV, Sachett JAG, et al. Accuracy of the Lee-White Clotting Time Performed in the Hospital Routine to Detect Coagulapathy in Bothrops atrox Envenomation. Am J Trop Med Hyg (2018) 98:1547-51. doi: 10.4269/ ajtmh.17-0992

182. Mckessy SP. Handbook of Venoms and Toxins of Reptiles. 1st ed. SP Mckessy, editor. Boca Raton, Florida: CRC Press (2009). Available at: https://www. taylorfrancis.com/books/mono/10.1201/9781420008661/handbookvenoms-toxins-reptiles-stephen-mackessy-stephen-mackessy.

183. Campbell JA, Lamar WW. The Venomous Reptiles of the Western Hemisphere. 1st ed. Ithaca, United States of America: Cornell University Press (2004). Available at: http://www.cornellpress.cornell.edu/book/? GCOI $=80140100664830$.

184. de Oliveira ATAL, de Sousa AFPB, Alcantara I de CL, de Miranda ITN, Marques RB. Acidentes com animais peconhentos no Brasil: revisão de literatura. Rev Intertox Toxicol RIsco Ambient E Soc (2018) 11:119-36. doi: 10.22280/revintervol11ed3.389

185. Otero-Patiño R. Epidemiological, clinical and therapeutic aspects of Bothrops asper bites. Toxicon (2009) 54:998-1011. doi: 10.1016/j.toxicon.2009.07.001

186. Warrell DA, Thorpe RS, Wüster W, Malhotra A. Venomous Snakes: Ecology, Evolution and Snakebite. Clarendon Press (1997) 1997:189-203. doi: $10.2307 / 1447318$

187. Gutiérrez JM. Snakebite envenoming in Latin America and the Caribbean. Toxinology (2013):51-72. doi: 10.1007/978-94-007-6288-6_14-2

188. Bucaretchi F, De Capitani EM, Branco MM, Fernandes LCR, Hyslop S. Coagulopathy as the main systemic manifestation after envenoming by a juvenile South American rattlesnake (Crotalus durissus terrificus): Case report. Clin Toxicol (2013) 51:505-8. doi: 10.3109/15563650.2013.802796

189. Cribari C. Management of Poisonous Snakebites. (2004). pp. 1-4. Available at: https://www.facs.org/ /media/files/quality programs/trauma/ publications/snakebite.ashx.

190. Yañez-Arenas C, Townsend Peterson A, Rodríguez-Medina K, Barve N. Mapping current and future potential snakebite risk in the new world. Clim Change (2016) 134:697-711. doi: 10.1007/s10584-015-1544-6

191. Longbottom J, Shearer FM, Devine M, Alcoba G, Chappuis F, Weiss DJ, et al. Vulnerability to snakebite envenoming: a global mapping of hotspots. Lancet (2018) 392:673-84. doi: 10.1016/S0140-6736(18)31224-8
192. World Health Organization. Regional Office for Africa. Guidelines for the prevention and clinical management of snakebite in Africa. World Health Organization. Regional Office for Africa (2010). Available at: https://apps. who.int/iris/handle/10665/204458.

193. Theakston RDG, Warrell DA. Crisis in snake antivenom supply for Africa. Lancet (2000) 356:2104. doi: 10.1016/S0140-6736(05)74319-1

194. World Health Organization. Rabies and envenomings: A neglected public health issue. World Health Organization (2007). Available at: https://apps. who.int/iris/bitstream/handle/10665/43858/9789241563482_eng.pdf? sequence $=1$ \&isAllowed $=y$.

195. Appiah B. Snakebite neglect rampant in Africa. Can Med Assoc J (2012) 184:27-8. doi: 10.1503/cmaj.109-4046

196. Habib AG, Brown NI. The snakebite problem and antivenom crisis from a health-economic perspective. Toxicon (2018) 150:115-23. doi: 10.1016/ j.toxicon.2018.05.009

197. Wood D, Sartorius B, Hift R. Classifying snakebite in South Africa: Validating a scoring system. South Afr Med J (2017) 107:46-51. doi: 10.7196/SAMJ.2017.v107i1.11361

198. Alirol E, Lechevalier P, Zamatto F, Chappuis F, Alcoba G, Potet J. Antivenoms for Snakebite Envenoming: What Is in the Research Pipeline? PloS Negl Trop Dis (2015) 9:1-11. doi: 10.1371/journal.pntd.0003896

199. Warrell DA. Unscrupulous marketing of snake bite antivenoms in Africa and Papua New Guinea: choosing the right product-'What's in a name?'. Trans $R$ Soc Trop Med Hyg (2008) 102:397-9. doi: 10.1016/j.trstmh.2007.12.005

200. Rogalski A, Sørensen CV, op den Brouw B, Lister C, Dashvesky D, Arbuckle $\mathrm{K}$, et al. Differential procoagulant effects of saw-scaled viper (Serpentes: Viperidae: Echis) snake venoms on human plasma and the narrow taxonomic ranges of antivenom efficacies. Toxicol Lett (2017) 280:159-70. doi: 10.1016/j.toxlet.2017.08.020

201. Abubakar IS, Abubakar SB, Habib AG, Nasidi A, Durfa N, Yusuf PO, et al. Randomised controlled double-blind non-inferiority trial of two antivenoms for Saw-scaled or carpet viper (Echis ocellatus) envenoming in Nigeria. PloS Negl Trop Dis (2010) 4:8-17. doi: 10.1371/journal.pntd.0000767

202. Simpson ID, Blaylock RSM. The anti snake venom crisis in Africa: A suggested manufacturers product guide. Wilderness Environ Med (2009) 20:275-82. doi: 10.1580/08-WEME-CON-296R1.1

203. Ouma PO, Maina J, Thuranira PN, Macharia PM, Alegana VA, English M, et al. Access to emergency hospital care provided by the public sector in subSaharan Africa in 2015: a geocoded inventory and spatial analysis. Lancet Glob Heal (2018) 6:e342-50. doi: 10.1016/S2214-109X(17)30488-6

204. Fry BG. Snakebite: When the Human Touch Becomes a Bad Touch. Toxins (Basel) (2018) 10:1-23. doi: 10.3390/toxins 10040170

205. Vaiyapuri S, Vaiyapuri R, Ashokan R, Ramasamy K, Nattamaisundar K, Jeyaraj A, et al. Snakebite and its socio-economic impact on the rural population of Tamil Nadu, India. PloS One (2013) 8:10-3. doi: 10.1371/ journal.pone. 0080090

206. Schioldann E, Mahmood MA, Kyaw MM, Halliday D, Thwin KT, Chit NN, et al. Why snakebite patients in Myanmar seek traditional healers despite availability of biomedical care at hospitals? Community perspectives on reasons. PloS Negl Trop Dis (2018) 12:1-14. doi: 10.1371/journal.pntd. 0006299

207. White P. The concept of diseases and health care in African traditional religion in Ghana. HTS Teol Stud/Theol Stud (2015) 71:1-7. doi: 10.4102/ hts.v71i3.2762

208. Hati AK, Mandal M, De MK, Mukerjee H, Hati RN. Epidemiology of snake bite in the district of Burdwan, West Bengal. J Indian Med Asoc (1992) 90:145-7.

209. Ediriweera DS, Kasturiratne A, Pathmeswaran A, Gunawardena NK, Jayamanne SF, Lalloo DG, et al. Health seeking behavior following snakebites in Sri Lanka: Results of an island wide community based survey. PloS Negl Trop Dis (2017) 11:1-11. doi: 10.1371/journal. pntd.0006073

210. Chippaux J-P. Snakebite in Africa: current situation and urgent needs. In: SP Mackessy, editor. Handbook of Venoms and Toxins of Reptiles. London: CRC Press. (2010) p. 453-73.

211. World Health Organization. Snakebite envenoming: A strategy for prevention and control. Geneva: World Health Organization (2019). 
212. de Castañeda RR, Durso AM, Ray N, Fernández JL, Williams DJ, Alcoba G, et al. Snakebite and snake identification: empowering neglected communities and health-care providers with AI. Lancet Digit Heal (2019) 1:e202-3. doi: 10.1016/S2589-7500(19)30086-X

213. Chippaux J-P. Epidemiology of snakebites in Europe: A systematic review of the literature. Toxicon (2012) 59:557-68. doi: 10.1016/j.toxicon.2011.10.008

214. Lamb T, de Haro L, Lonati D, Brvar M, Eddleston M. Antivenom for European Vipera species envenoming. Clin Toxicol (2017) 55:557-68. doi: $10.1080 / 15563650.2017 .1300261$

215. Brvar M, Kurtović T, Grenc D, Lang Balija M, Križaj I, Halassy B. Vipera ammodytes bites treated with antivenom ViperaTAb: a case series with pharmacokinetic evaluation. Clin Toxicol (2017) 55:241-8. doi: 10.1080/ 15563650.2016 .1277235

216. Varga C, Malina T, Alföldi V, Bilics G, Nagy F, Oláh T. Extending knowledge of the clinical picture of Balkan adder (Vipera berus bosniensis) envenoming: The first photographically-documented neurotoxic case from South-Western Hungary. Toxicon (2018) 1:29-35. doi: 10.1016/j.toxicon.2017.12.053

217. Malina T, Krecsak L, Warrell DA. Neurotoxicity and hypertension following European adder (Vipera berus berus) bites in Hungary: case report and review. QJM (2008) 101:801-6. doi: 10.1093/qjmed/hcn079

218. Latinović Z, Leonardi A, Šribar J, Sajevic T, Žužek MC, Frangež R, et al. Venomics of Vipera berus berus to explain differences in pathology elicited by Vipera ammodytes ammodytes envenomation: Therapeutic implications. J Proteomics (2016) 146:34-47. doi: 10.1016/j.jprot.2016.06.020

219. Ferquel E, de Haro L, Jan V, Guillemin I, Jourdain S, Teynié A, et al. Reappraisal of Vipera aspis Venom Neurotoxicity. PloS One (2007) 2:e1194. doi: 10.1371/journal.pone.0001194

220. Westerström A, Petrov B, Tzankov N. Envenoming following bites by the Balkan adder Vipera berus bosniensis - first documented case series from Bulgaria. Toxicon (2010) 56:1510-5. doi: 10.1016/j.toxicon.2010.08.012

221. Magdalan J, Trocha M, Merwid-Ld A, Sozaski T, Zawadzki M. Vipera berus bites in the region of southwest Poland - A clinical analysis of 26 cases. Wilderness Environ Med (2010) 21:114-9. doi: 10.1016/j.wem. 2010.01.005

222. Persson H. Pathophysiology and Treatment of Envenomation by European Vipers. Springer Netherlands, (2018) 357-75. doi: 10.1007/978-94-0177438-3_9

223. Petite J. Viper bites: Treat or ignore? Swiss Med Wkly (2005) 135:618-25.

224. Karlson-Stiber C, Salmonson H, Persson H. A nationwide study of Vipera berus bites during one year - Epidemiology and morbidity of 231 cases. Clin Toxicol (2006) 44:25-30. doi: 10.1080/15563650500394597

225. Hønge BL, Hedegaard SK, Cederstrøm S, Nielsen H. Hospital contacts after bite by the European adder (Vipera berus). Dan Med J (2015) 62:1-6.

226. Pucca MB, Knudsen C, Oliveira IS, Rimbault C, Cerni FA, Wen FH, et al. Current Knowledge on Snake Dry Bites. Toxins (Basel) (2020) 12:4-7. doi: $10.3390 /$ toxins 12110668

227. Montag A. Giftschlangen in Deutschland und Europa. Zentralblatt für Arbeitsmedizin Arbeitsschutz und Ergon (2018) 68:287-308. doi: 10.1007/ s40664-018-0301-x

228. Kollander Jakobsen L, Lyhne JA. Hugormebid, symptomer undersøgelse og behandling (2018). Akutmodtagelse Thisted, Aalborg Univ Reg Nord. Available at: https://pri.rn.dk/Sider/16734.aspx (Accessed May 31, 2018).

229. Guiavarch M, Médus M, Tichadou L, Glaizal M, de Haro L. Efficacité variable de l'antivenin Viperfav pour traiter les envenimations vipérines avec neurotoxicité. Press Medicale (2011) 40:654-6. doi: 10.1016/j.lpm. 2011.01.023

230. Zanetti G, Duregotti E, Locatelli CA, Giampreti A, Lonati D, Rossetto O, et al. Variability in venom composition of European viper subspecies limits the cross-effectiveness of antivenoms. Sci Rep (2018) 8:1-9. doi: 10.1038/ s41598-018-28135-0

231. García-Arredondo A, Martínez M, Calderón A, Saldivar A, Soria R. Preclinical assessment of a new polyvalent antivenom (Inoserp europe) against several species of the subfamily viperinae. Toxins (Basel) (2019) 11:149. doi: 10.3390/toxins 11030149

232. Casewell NR, Al-Abdulla I, Smith D, Coxon R, Landon J. Immunological Cross-Reactivity and Neutralisation of European Viper Venoms with the Monospecific Vipera berus Antivenom ViperaTAb. Toxins (Basel) (2014) 6:2471-82. doi: 10.3390/toxins6082471
233. Valenta J, Stach Z, Michálek P. Severe Snakebite Envenoming in Intensive Care. Prague Med Rep (2016) 117:153-63. doi: 10.14712/23362936.2016.16

234. Schaper A, Desel H, Ebbecke M, De Haro L, Deters M, Hentschel H, et al. Bites and stings by exotic pets in Europe: An 11 year analysis of 404 cases from Northeastern Germany and Southeastern France. Clin Toxicol (2009) 47:39-43. doi: 10.1080/15563650801954875

235. Schaper A, De Haro L, Desel H, Ebbecke M, Langer C. Rattlesnake bites in Europe - Experiences from Southeastern France and Northern Germany. J Toxicol - Clin Toxicol (2004) 42:635-41. doi: 10.1081/CLT-200026962

236. Lonati D, Butera R, Cima M, Cozzio S, Locatelli C, Manzo L. Exotic snakes in Europe - A case of Mexican moccasin (Agkistrodon bilineatus) snakebite. Press Medicale (2004) 33:1582-4. doi: 10.1016/S0755-4982(04)98997-X

237. Alfred S, Bates D, White J, Mahmood MA, Warrell DA, Thwin KT, et al. Acute Kidney Injury Following Eastern Russell's Viper (Daboia siamensis) Snakebite in Myanmar. Kidney Int Rep (2019) 4:1337-41. doi: 10.1016/ j.ekir.2019.05.017

238. Pinho FMO, Zanetta DMT, Burdmann EA. Acute renal failure after Crotalus durissus snakebite: A prospective survey on 100 patients. Kidney Int (2005) 67:659-67. doi: 10.1111/j.1523-1755.2005.67122.x

239. Mise YF, Lira-da-Silva R, Carvalho FM. Time to treatment and severity of snake envenoming in Brazil. Rev Panam Salud Pública (2018) 42:e52. doi: 10.26633 RPSP.2018.52

240. Silva A, Hlusicka J, Siribaddana N, Waiddyanatha S. Time delays in treatment of snakebite patients in rural Sri Lanka and the need for rapid diagnostic tests. PloS Negl Trop Dis (2020) 14(11):e0008914. doi: 10.1371/ journal.pntd.0008914

241. Gutiérrez JM, Fan HW, Silvera CLM, Angulo Y. Stability, distribution and use of antivenoms for snakebite envenomation in Latin America: Report of a workshop. Toxicon (2009) 53:625-30. doi: 10.1016/j.toxicon.2009.01.020

242. Gutiérrez JM. Current challenges for confronting the public health problem of snakebite envenoming in Central America. J Venom Anim Toxins Incl Trop Dis (2014) 20:1-9. doi: 10.1186/1678-9199-20-7

243. Williams HF, Vaiyapuri R, Gajjeraman P, Hutchinson G, Gibbins JM, Bicknell $\mathrm{AB}$, et al. Challenges in diagnosing and treating snakebites in a rural population of Tamil Nadu, India: The views of clinicians. Toxicon (2017) 130:44-6. doi: 10.1016/j.toxicon.2017.02.025

244. Harrison RA, Gutiérrez JM. Priority Actions and Progress to Substantially and Sustainably Reduce the Mortality, Morbidity and Socioeconomic Burden of Tropical Snakebite. Toxins (Basel) (2016) 8:351. doi: 10.3390/ toxins8120351

245. Hifumi T, Sakai A, Kondo Y, Yamamoto A, Morine N, Ato M, et al. Venomous snake bites: clinical diagnosis and treatment. J Intensive Care (2015) 3:1-9. doi: 10.1186/s40560-015-0081-8

246. Theakston RDG, Laing GD. Diagnosis of snakebite and the importance of immunological tests in venom research. Toxins (Basel) (2014) 6:1667-95. doi: $10.3390 /$ toxins 6051667

247. Laustsen AH, Dorrestijn N. Integrating Engineering, Manufacturing, and Regulatory Considerations in the Development of Novel Antivenoms. Toxins (Basel) (2018) 10(8):309. doi: 10.3390/toxins10080309

248. Williams HF, Layfield HJ, Vallance T, Patel K, Bicknell AB, Trim SA, et al. The urgent need to develop novel strategies for the diagnosis and treatment of snakebites. Toxins (Basel) (2019) 11:1-29. doi: 10.3390/toxins11060363

249. Sweet D, Lorente JA, Valenzuela A, Lorente M, Villanueva E. PCR-based DNA typing of saliva stains recovered from human skin. J Forensic Sci (1997) 42:447-51. doi: 10.1520/JFS14146J

250. Puzari U, Mukherjee AK. Recent developments in diagnostic tools and bioanalytical methods for analysis of snake venom: A critical review. Anal Chim Acta (2020) 1137:208-24. doi: 10.1016/j.aca.2020.07.054

251. Bawaskar HS, Bawaskar PH, Bawaskar PH. Snake bite in India: a neglected disease of poverty. Lancet (2017) 390:1947-8. doi: 10.1016/S0140-6736(17) 32175-X

252. Gutiérrez JM, Burnouf T, Harrison RA, Calvete JJ, Kuch U, Warrell DA. A multicomponent strategy to improve the availability of antivenom for treating snakebite envenoming. Bull World Health Organ (2014) 92:52632. doi: 10.2471/BLT.13.132431

253. Neuzil P, Zhang C, Pipper J, Oh S, Zhuo L. Ultra fast miniaturized real-time PCR: 40 cycles in less than six minutes. Nucleic Acids Res (2006) 34:e77. doi: $10.1093 / \mathrm{nar} / \mathrm{gkl} 416$ 
254. Vaagt F, Haase I, Fischer M. Loop-mediated isothermal amplification (LAMP)-based method for rapid mushroom species identification. J Agric Food Chem (2013) 61:1833-40. doi: 10.1021/jf304824b

255. Jiang C, Yuan Y, Liu L, Hou J, Jin Y, Huang L. Homogeneous fluorescent specific PCR for the authentication of medicinal snakes using cationic conjugated polymers. Sci Rep (2015) 5:1-7. doi: 10.1038/srep16260

256. World Health Organization. Guidelines for the management of snakebite. 2nd Edition. World Health Organization (2016). Available at: https://www.who. int/snakebites/resources/9789290225300/en/.

257. Seqirus and Snake Venom Detection Kit Product Leaflet. (2017). https:// labeling.seqirus.com/SVDK/AU/Snake-Venom-Detection-Kit/EN/SnakeVenom-Detection-Kit.pdf.

258. Isbister GK, Maduwage K, Shahmy S, Mohamed F, Abeysinghe C. Diagnostic 20-min whole blood clotting test in Russell's viper envenoming delays antivenom administration. QJM - Int J Med (2013) 106:925-32. doi: 10.1093/qjmed/hct102

259. Seifert SA, Boyer LV. Recurrence phenomena after immunoglobulin therapy for snake envenomations: Part 1. Pharmacokinetics and pharmacodynamics of immunoglobulin antivenoms and related antibodies. Ann Emerg Med (2001) 37:189-95. doi: 10.1067/mem.2001.113135

260. Ho M, Warrell DA, Looareesuwan S, Phillips RE, Chanthavanich P, Karbwang J, et al. Clinical significance of venom antigen levels in patients envenomed by the Malayan pit viper (Calloselasma rhodostoma). Am J Trop Med Hyg (1986) 35:579-87. doi: 10.4269/ajtmh.1986.35.579

261. Faiz MA, Ahsan MF, Ghose A, Rahman MR, Amin R, Hossain M, et al. Bites by the Monocled Cobra, Naja kaouthia, in Chittagong Division, Bangladesh: Epidemiology, Clinical Features of Envenoming and Management of 70 Identified Cases. Am J Trop Med Hyg (2017) 96:876-84. doi: 10.4269/ ajtmh.16-0842

262. Rojnuckarin P, Banjongkit S, Chantawibun W, Akkawat B, Juntiang J, Noiphrom J, et al. Green pit viper (Trimeresurus albolabris and T. macrops) venom antigenaemia and kinetics in humans. Trop Doct (2007) 37:207-10. doi: 10.1258/004947507782332838

263. Sanhajariya S, Duffull SB, Isbister GK. Pharmacokinetics of snake venom. Toxins (Basel) (2018) 10:73. doi: 10.3390/toxins10020073

264. Fassett RG, Venuthurupalli SK, Gobe GC, Coombes JS, Cooper MA, Hoy WE. Biomarkers in chronic kidney disease: A review. Kidney Int (2011) 80:806-21. doi: 10.1038/ki.2011.198

265. Wang SQ, Sarenac D, Chen MH, Huang SH, Giguel FF, Kuritzkes DR, et al. Simple filter microchip for rapid separation of plasma and viruses from whole blood. Int J Nanomed (2012) 7:5019-28. doi: 10.2147/IJN.S32579

266. Tang RH, Yang H, Choi JR, Gong Y, Feng SS, Pingguan-Murphy B, et al. Advances in paper-based sample pretreatment for point-of-care testing. Crit Rev Biotechnol (2017) 37:411-28. doi: 10.3109/07388551.2016.1164664

267. Sajid M, Kawde A-N, Daud M. Designs, formats and applications of lateral flow assay: A literature review. J Saudi Chem Soc (2015) 19:689-705. doi: 10.1016/j.jscs.2014.09.001

268. Deonarain MP, Yahioglu G, Stamati I, Marklew J. Emerging formats for next-generation antibody drug conjugates. Expert Opin Drug Discovery (2015) 10:463-81. doi: 10.1517/17460441.2015.1025049

269. Sørensen CV, Knudsen C, Auf Dem Keller U, Kalogeropoulos K, GutiérrezJiménez C, Pucca MB, et al. Do Antibiotics Potentiate Proteases in
Hemotoxic Snake Venoms? Toxins (Basel) (2020) 12:1-6. doi: 10.3390/ toxins 12040240

270. Morrison JJ, Pearn JH, Covacevich J, Nixon J. Can Australians identify snakes? Med J Aust (1983) 2:66-70. doi: 10.5694/j.1326-5377.1983.tb142105.x

271. Viravan C, Looareesuwan S, Kosakam W, Wuthiekanun V, McCarthy CJ, Stimson AF, et al. A national hospital-based survey of snakes responsible for bites in Thailand. Trans R Soc Trop Med Hyg (1992) 86:100-6. doi: 10.1016/ 0035-9203(92)90463-M

272. Ariaratnam CA, Rezvi Sheriff MH, Arambepola C, Theakston RDG, Warrell DA. Syndromic approach to treatment of snake bite in Sri Lanka based on results of a prospective national hospital-based survey of patients envenomed by identified snakes. Am J Trop Med Hyg (2009) 81:725-31. doi: 10.4269/ ajtmh.2009.09-0225

273. Sulaiman SS, Kharusha IK, Samara AM, Al-Jabi SW, Zyoud SH. An assessment of medical students' proficiency in the diagnosis and management of snakebites: A cross-sectional study from Palestine. J Occup Med Toxicol (2020) 15:1-11. doi: 10.1186/s12995-020-00254-3

274. White J. Clinical toxinology specialty training. Toxicon (2013) 69:120-5. doi: 10.1016/j.toxicon.2013.03.007

275. Gutiérrez JM, Williams D, Fan HW, Warrell DA. Snakebite envenoming from a global perspective: Towards an integrated approach. Toxicon (2010) 56:1223-35. doi: 10.1016/j.toxicon.2009.11.020

276. Harrison RA, Casewell NR, Ainsworth SA, Lalloo DG. The time is now: A call for action to translate recent momentum on tackling tropical snakebite into sustained benefit for victims. Trans R Soc Trop Med Hyg (2019) 113:834-7. doi: 10.1093/trstmh/try134

277. Williams D, Gutiérrez JM, Harrison R, Warrell DA, White J, Winkel KD, et al. The Global Snake Bite Initiative: an antidote for snake bite. Lancet (2010) 375:89-91. doi: 10.1016/S0140-6736(09)61159-4

278. Williams DJ, Gutiérrez JM, Calvete JJ, Wüster W, Ratanabanangkoon K, Paiva OK, et al. Ending the drought: New strategies for improving the flow of affordable, effective antivenoms in Asia and Africa. J Proteomics (2011) 74:1735-67. doi: 10.1016/j.jprot.2011.05.027

Conflict of Interest: CK, JJ, AH, RF, SD, and AL are shareholders in VenomAid Diagnostics ApS. CK is enrolled in an industrial $\mathrm{PhD}$ programme sponsored partially by the company BioPorto Diagnostics A/S, and is therefore employed by this company.

The remaining authors declare that the research was conducted in the absence of any commercial or financial relationships that could be construed as a potential conflict of interest.

The handling editor declared a past co-authorship with several of the authors, CK, JJ, and AL.

Copyright (c) 2021 Knudsen, Jürgensen, Føns, Haack, Friis, Dam, Bush, White and Laustsen. This is an open-access article distributed under the terms of the Creative Commons Attribution License (CC BY). The use, distribution or reproduction in other forums is permitted, provided the original author(s) and the copyright owner(s) are credited and that the original publication in this journal is cited, in accordance with accepted academic practice. No use, distribution or reproduction is permitted which does not comply with these terms. 